\title{
DRAFIClimate Change Adaptation Indicators Framework for the City of Boston, MA
}

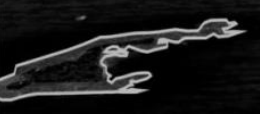
so 2
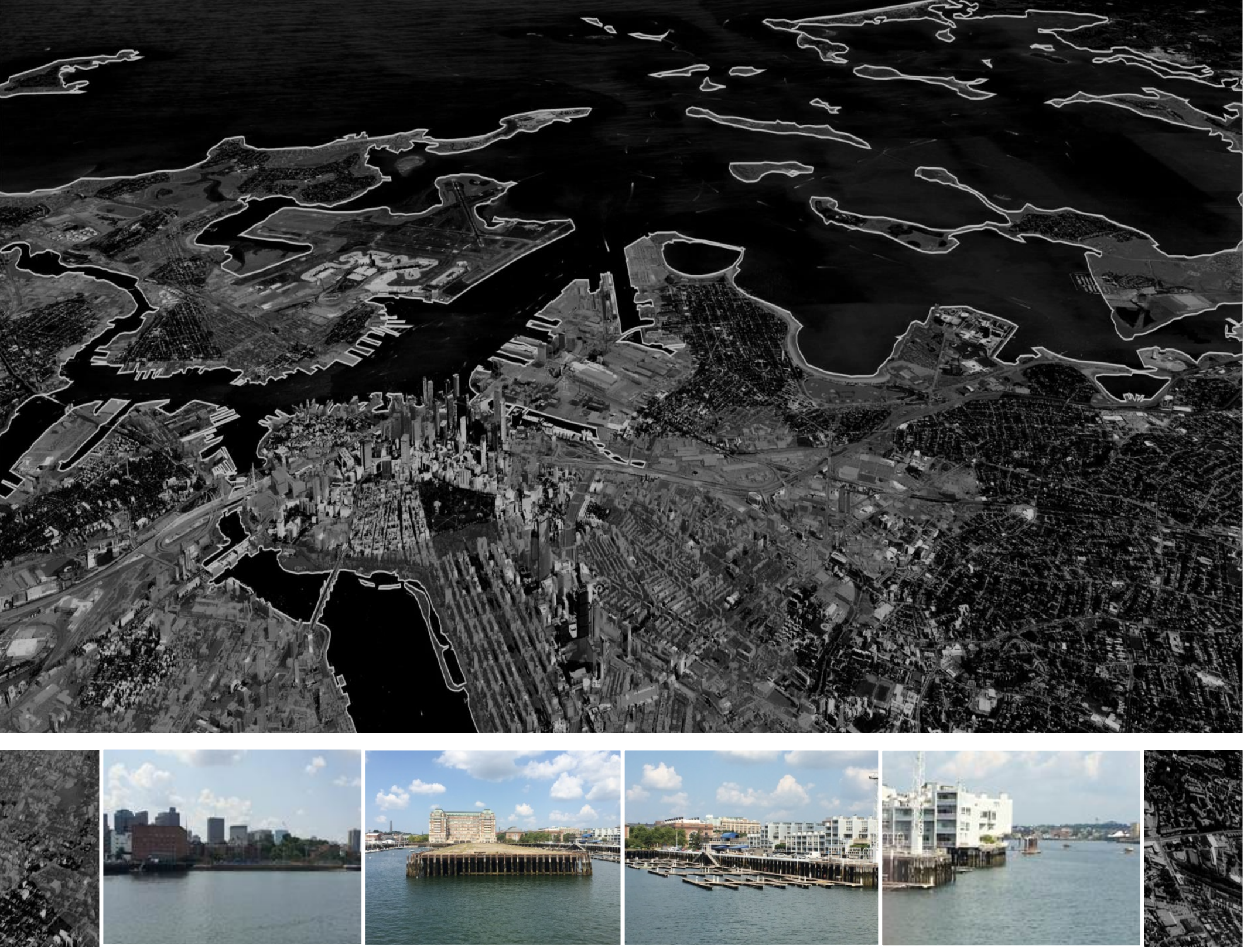


\section{ABSTRACT}

Despite global efforts to mitigate climate change, climate change impacts are occuming, and will likely increase in severity in the coming decades. The City of Boston hasstated its commitment to mitigating climate change and preparing the city for its impacts through the establishment of the Climate Action Plan (2010). Through their report, the Climate Action Leadership Committee and the Community Advisory Committee of the City of Boston established the need for an indicators framework to track the progress of the City of Boston in preparing for climate change. "A Draft Climate Adaptation Indic ators Fra mework for the City of Boston, MA" provides a pragmatic approach to establishing indic ator metric s to better understand the City of Boston's vulnera bilities and to evaluate and track its progress in implementing preparedness and resilience mea sures. This report describes the four-step methodology to develop a climate change adaptation (CCA) ind ic ators framework, the resulting draft CCA indicators framework, and recommendations for next steps in implementing and honing this framework.

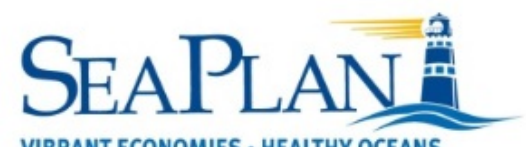

VIBRANT ECONOMIES • HEALTHY OCEANS

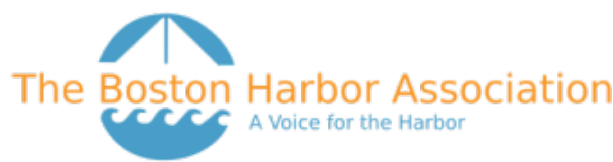

Cover Images: “High Tide During a 100-Year Storm in the Year 2050 with 2 Feet of Projected Sea Level Rise" by Sasaki Associates; photographs of Downtown Boston courtesy of Andy Lipsky.
PRIMARY AUTHORS

Andy Lipsky, Senior Partner, SeaPla n

Kim Starbuck, Project Manager, SeaPlan

CONTRIBUTORS

J UUE Wormser, EXEC UTIVE DiRECTOR, THE Boston HARBor ASSOCIATION

CARL SPECTOR, DIREC TOR OF C LMATE AND ENVIRONMENTAL PlanNing, CITY OF BOSTON

RACHEL M. G REg G, LEAD SCIENTIST, EC OAdAPT

LORA J . HANSEN, C HIEF SCIENTIST, ECOADAPT

J ANUARY 2015

RECOMMENDED CITATION:

Lipsky, A. and Starbuck, K. SeaPlan. Climate Change Indic ators Fra mework for the City of Boston, MA. J anuary 2015. Boston: Doc \#220.14.02

\section{SUPPORTFOR THIS PROJ ECTPROVIDED BY}

THE BARR FOUNDATION

This report (doc \# 220.14.02) was prepared by SeaPlan and may be downloaded at www.SeaPlan.org.

SeaPlan

89 South Street, Suite 202

Boston, MA 02111 


\section{Table of Contents}

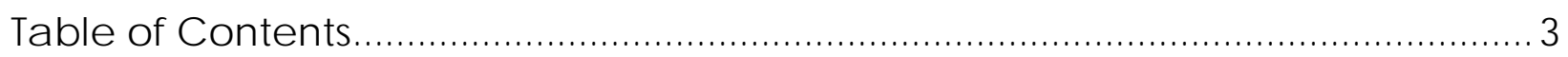

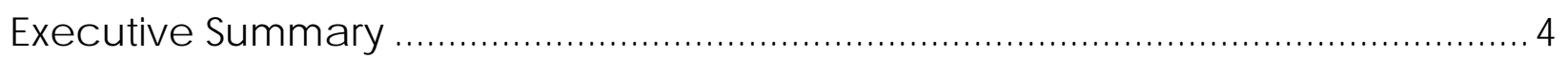

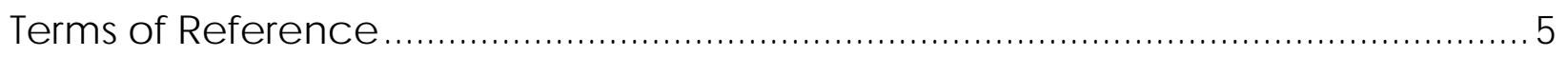

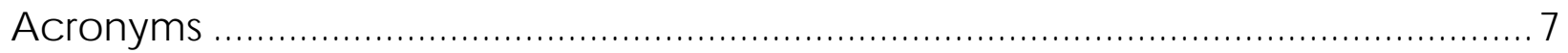

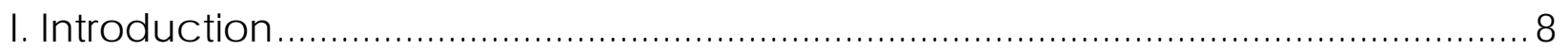

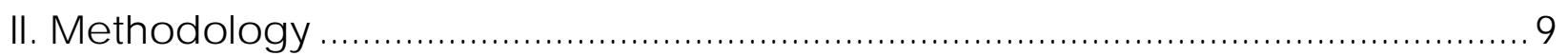

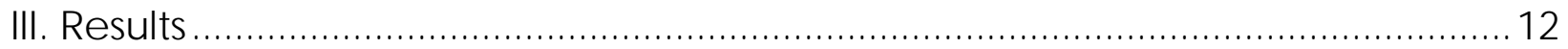

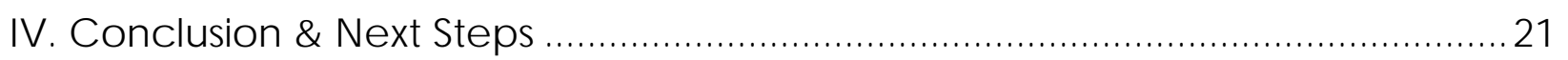

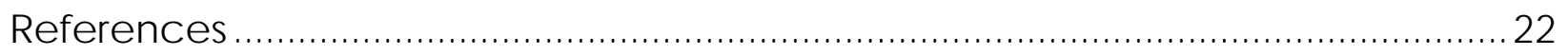

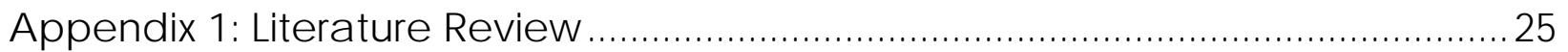

I. Guidebooks, Toolkits, and Reference Materia Is for Developing a CCA Ind ic a to rs Fra mework .................................................................................................... 25

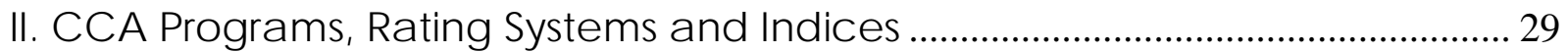

III. Climate Change Documents Specific to Boston .................................................. 36

Appendix 2: List of Potential Indic ators to Mea sure Climate Change

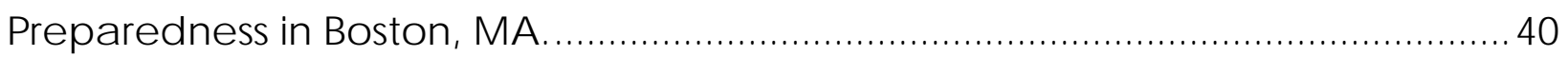




\section{Exec utive Summary}

Despite global efforts to mitigate climate change, climate change impacts are occurning, and will likely increase in seventy in the coming decades. Current models predict Boston will experience up to two feet of sea-level rise by 2050 and up to six feet by 2100 . Because of this, it is imperative for decision makers and the public to determine how to adapt to and prepare for the changing climate, as well as understand the effectiveness of their adaptation-related management actions through monitoring and evaluation to inform future decisions.

The City of Boston has committed to mitigating clima te change and preparing the city for its impacts through the establishment of the Climate Action Plan (2010) and the recently released 2014 Climate Action Plan Update. Through these efforts, the City of Boston established the need for an indicators framework to track the progress of the City of Boston in preparing for c lima te change. The 2014 CAP calls for the establishment of preparedness ind ic ators (Action 2.32 in the 2014 CAP). SeaPlan, the Boston Harbor Association (TBHA), and EcoAdapt have collaborated with the City of Boston to develop this draft clima te adaptation indic a tors framework to help fill this need. This document has been informed by the CAP Update process and reflects the formative work the City has already accomplished in identifying and beginning to address its c limate prepa redness and resilience priorities. In a ddition, this draft fra mework builds on the ongoing and previous work conducted by the City and its clima te action partners and builds on the best available science and policy from national and intemational clima te change adaptation (CCA) indicator programs.

The following draft report describes the team's methodology, the resultant Draft CCA framework, and recommendations for the next steps to further develop an indic ators framework. The team's four-step approach to devising the Draft CCA indicators fra mework included a literature review of the best ava ilable science and polic y from national and intemational c limate adaptation ind ic ators programs, the identific a tion of sectors in Boston involved with and/or impacted by climate change, the development of CCA indicators and metric sinformed by the literature, and the development of a refined list of indicators specific to the needs and priorities of the City of Boston. The results a re six high-level ind ic a tors and associated metrics which can be applied to mea sure the City of Boston's preparedness for clima te change. 


\section{Terms of Reference}

Adaptation: Adjustment in na tural or human systems in response to actual or expected c limac tic stimuli or their effects, which moderates ham or exploits benefic ial opportunities (IPCC 2007)

Adaptive capacity: The ability of human systems to adapt to and cope with climate change depends on such factors as wealth, tec hnology, educ a tion, information, skills, infrastructure, access to resources, and management capabilities (IPCC 2007)

Adaptation indicators: Indic ators that focus on both a) planned adaptation to climate change and b) the actual state of adaptation a chieved (see definitions of indic ator, process and outc ome below) (Sniffer 2012, VI)

Baseline: A baseline is the situation before a marine spatia I management plan begins; it is the starting point for performance monitoring and evaluation of each performance indicator (Ehler 2014, IX)

Climate change: Any signific a nt change in the mea sures of c limate lasting for an extended period of time, i.e. major changes in temperature, precipitation, or wind pattems that occ ur over several dec ades or longer (US EPA 2014)

Climate change adaptation: Adjustment in natural or human systems in resp onse to ac tual or expected climatic stimuli or their effects, which moderates harm or exploits benefic ial opportunities. Va rious types of a daptation can be distinguished, including antic ipa tory, autonomous and planned adaptation (IPCC, 2007)

Climate change mitigation: An a nthropogenic intervention to reduce the sources or enhance the sinks of greenhouse gases (IPCC 2007)

Climate impacts: The effects of climate change on natural and human systems. Depending on the consideration of adaptation, one can distinguish between potential impacts and residual impacts (IPCC 2007)

Climate preparedness: The effort to reduce the risks related to climate change and to prepare for responding to new conditions (Spector and Bamberger 2013)

Evaluation (of adaptation measure): A process for systema tic a lly and objec tively determining the effectiveness of an a daptation measure in the light of its objectives (UNFC CC 2010, 4)

Indicators: An indicator is a mea sure of something that we want to know the condition of or that we want to track (e.g., environmental condition). Indica tors help us understand where we are, where we are going, and how far we are from the goal (US EPA Region 3 2014) 
Outc ome indicators: Indic ators that measure the effectiveness of adaptation polic ies and activities (Ha rley et al. 2008, iii)

Process indic ators: Ind ic ators that monitor the progress in implementing a daptation mea sures (Ha rley et al. 2008, iii)

Resilience: (1) The ability to recover from or adjust easily to misfortune or change (Memiam-Webster, 2015); (2) The ability to prepare and plan for, absorb, recover from, or more successfully a dapt to actual or potential a dverse effects (National Research Council 2012, 12); (3) The capacity to adapt to changing conditions and to mainta in or rega in func tionality and vita lity in the face of stress or disturbance (Wilson 2013; Newman et al. 2013, 5)

Risk: The potential for a n unwanted outcome resulting from an inc ident, event or occurrence, as determined by its likelihood and the associated consequences (DHS 2008, Newman et al. 2013, 17)

Vulnerability (related to climate change): Vulnerability is the degree to which a system is susceptible to, and unable to cope with, adverse effects of climate change, including climate variability and extremes. Vulnerability is a function of the character, magnitude, and rate of climate change and variation to which a system is exposed, its sensitivity, and its adaptive capacity (IPCC 2007) 


\section{Acronyms}

ADAPT- Adaptive Leaming, Dyna mic Monitoring, Active, Participa tory, Thorough

AdaptME - Adaptation Monitoring and Evaluation

CAP - Climate Action Plan

CCA - Climate Change Adaptation

CCVI - Climate Change Vulnerability Index

CVM - Clima te Vulnera bility Monitor

EPI - Environmental Performance Index

FMA - Federal Emergency Management Agency

IIED - Intemational Institute for Environment and Development

MA Plan - Massachusetts Ocean Management Plan

MA CZM - Massac husetts Coastal Zone Management

ND-GAIN - University of Notre Dame Global Adaptation Index

STAR Communities - Susta ina ble Tools for Assessing and Rating Communities

SMART-Specific, Measurable, Atta inable/Achievable, Relevant, Time bound

TACCIMO - Template for Assessing Climate Change Impacts \& Management Options

TAMD - Tracking Adaptation Measuring Development

TBHA - The Boston Harbor Association

UKCIP - United Kingdom Climate Impacts Program

UNISDR - United Nations Office for Disaster Risk Reduction

USDA - United States Department of Agric ulture

WMF - World Wild life Fund 


\section{Introduction}

Despite the various mitigation efforts occuring throughout the world, the impacts of c limate change will likely still be large (Harley, 2008). As one exa mple, current models predict Boston will experience up to two feet of sea level rise by 2050 and up to six feet by 2100 . Because of this, it is imperative for decision makers and the public to determine how to adapt to and prepare for the changing climate, as well as understand the effectiveness of their adaptation-related management actions through monitoring and evaluation to inform future decisions.

The City of Boston (the City) committed to leading a public process to identify and implement actions to expand climate change preparedness beyond municipal agencies. The results of this process formed the basis of a revised Climate Action Plan (CAP) completed in 2014. As part of the CAP, the City previously developed indicators to track c lima te change mitigation, but has yet to develop indic ators to track the City's progress with climate change adaptation. The 2014 CAP calls for the establishment of preparedness indic ators (Action 2.32 in the 2014 CAP, p. 64); and this draft framework should assist in the City's efforts to camy out these efforts.

To help fill this gap, SeaPlan, the Boston Harbor Association (TBHA), and EcoAdapt (the tea $\mathrm{m}$ ) worked with the $\mathrm{C}$ ity to develop a climate change adaptation indic ators framework for potential use by the City. The draft framework conta ins key high level indicators, as well as potential metric s that provide more specific information about the high level indic ators and could be used by the City when measuring the indicators. These metric s were primarily adapted from the data completed through the literature review found in Appendix 1 and represent initial thinking on how these indic ators could be measured. The proposed indicators and metric s should be further reviewed by the City of Boston and the Climate Change Preparedness Strategic Committee, and revised as needed.

The following document conta ins a methodology section which provides an overview of how the team developed the CCA indic ators framework, starting with a literature review to identify best practic es and the use of sc reening criteria to namow down a comprehensive list of potential ind ic a tors. The results section of this doc ument conta ins the proposed CCA framework for Boston, and the conclusion section conta ins recommended next steps for continuing to refine this framework and developing an c limate adaptation indic a tors system for the City. 


\section{Methodology}

To develop the CCA indicators framework, the team devised a four- step methodology which included:

- Step 1: Conduct Literature Review

- Step 2: Identify Sectors in Boston Likely Impacted by Clima te Change

- Step 3: Develop Comprehensive List of Potential C limate Change Adaptation Indic a tors

- Step 4: Develop Clima te Change Adaptation Indic a tors Fra mework for Boston

More details on each step can be found below.

\section{Step 1: Conduct Literature Review}

As a first step to developing a CCA ind ic a tors fra mework for Boston, the team conducted a comprehensive literature review to ensure this effort is ba sed on current best practices in the climate change adaptation field. More specifically, the team used the following screening criteria when selecting literature to review:

- Years: 2005 - 2014

- Geography: Local, national (U.S.), and intemational sources

- Type:

o CCA guidebooks

- CCA academic papers

- CCA programs, indic es and rating systems (city, national and intemational)

o Climate change-related documents published by the City of Boston

Through reviewing this litera ture, SeaPlan collected information on:

- The process of designing a CCA indicators framework, including the need for and purpose for evaluating climate change adaptation actions, as well as the challenges associa ted with adaptation ind ic a tor selection

- Artic ulated recommenda tions for CCA indic a tor selection, including:

- Cha racteristic s of the indic a tors (e.g., process or outc ome ind ic ator)

- Data a vailability

- General best practices

o Linking indicators to policy initiatives

- Sectors within cities/communities that will likely be impacted by clima te change or involved with climate change adaptation (e.g., transportation, electric ity/fuel, residential neighborhoods)

- Clima te change-related policy goals articulated by Boston which will be useful when selecting ind ic a tors that a re aligned with Boston's adaptation priorities

- The goals, indic a tors selected (when applicable), and lessonsleamed from other 
CCA programs from a round the world, specific a lly focusing on each program's applic a bility to Boston

For a full ovenview of the litera ture reviewed and its applic a bility to Boston, see Appendix 1.

\section{Step 2: Identify Sectors in Boston Impacted by/Addressed through Climate Change Adaptation Efforts}

1. Govemance \& Govemment

2. Business \& Institutions

3. Social \& Natural Capital

4. Residential Neighborhoods

5. Public Health \& Safety

6. Transportation Infrastruc ture

7. Food, Water, Sewer, \& Protec tive Infrastruc ture

8. Telecommunic ations

9. Elec tric ity \& Fuel

10. Community Outreach \& Public Engagement

\section{Step 3: Develop Comprehensive List of Potential Indic ators}

Based on the literature review and previous work conducted by the City of Boston, the tea $\mathrm{m}$ compiled a comprehensive list of potential clima te change a daptation indic ators and organized the indic ators by sectors (Appendix 2). Following Ayers (2012), the team looked for indic ators that a nswered the following questions:

How would we know that change has happened in this outcome?

How will we know success when we see it?

What would be the evidence of this change?

In addition, the team identified indic ators that were related to Boston's top priorities regarding climate change adaptation, as well as the draft strategies identified for the 2014 Climate Action Plan by the Boston's Climate Preparedness Strategic Committee.

\section{Step 4: Develop Climate Change Adaptation Indic ators Framework for Boston}

Based on best practic es in CCA indic a tor selection, the team narrowed down the long list of potential indicators using the following criteria:

- Indic ators that a re linked to Boston's articulated climate change adaptation priorities (either in the 2014 Draft CAP or previous polic y doc uments) (e.g., reducing vulnerability, coordination between govemment agencies, emergency response, establishing polic y definitions)

- Indic ators that a re foc used on changing conditions and the Plan being adaptive and flexible 
- Top level or overarching indica tors that capture a number of important climate change adaptation topic s that are most relevant to Boston and Northeastem United Sta tes communities

- Indic a tors that a im to complement the mitigation goals outlined in the Boston CAP to decrease the rate and extent of climate change (e.g., decrease greenhouse gases, urban forestry)

- Indic ators that aim to a void maladaptation

- Indic ators that form a broad suite that include both process and outc ome indicators

In addition, the team selected potential metric s that provide more specific information about the high level indicators and could be used by the City to measure the broad level indic ators. 


\section{Results}

The fra mework consists of six high-level indic ators, inc lud ing:

1) Institutional Planning, Capacity and Coordination;

2) Climate Science and Information;

3) Public/StakeholderEngagement and Awa reness;

3) Public Health and Sa fety;

5) Natural Resources and Coastal Infrastruc ture; and

6) Public/Private Buildings and Utilities.

Each high-level indic ator conta ins potential metric s that provide more specific s about the indic ator and could be used by the City when measuring the indic ator. These metrics were primarily adapted from data and information compiled in Appendix 1 , and represent initial thinking on how these indic a tors could be measured. The draft fra mework appears on the following pages of this document. 
Indicator: The degree to which planning, capacity and coordination to effectively prepare for and respond to climate change and extreme weather events is in place. Climate change is mainstreamed into city plans and programs. Finances and resources are available to a dequately address climate change and related events. Govemment is able to continue operating and providing critic al servic es during c limate-rela ted events.

Includes:

- General govemment capacity and planning for climate change;

- Govemment continuity, planning and capacity specific to emergency response;

- Operational coord ination, inter and intra-city coordination, regional planning, and coordination of resources/infra struc ture not under city jurisdic tion; and

- Support for ma instrea ming clima te change into planning, incentivizing resilience (e.g., businesses are prepared to continue operating during climate change related events).

Indicatortype: Enhance preparedness/readiness.

\section{Metrics:}

General govemment planning and capacity -

- Goveming structure has established policy definitions for 1 ) required planning horizons (e.g., end of the century), 2) expected future conditions, and 3) "acceptable risk" from coastal flooding, extreme precipitation and heat.

- Plans are adaptive and flexible; preparedness plans and associa ted regulations and incentives are indexed to monitored environmental conditions (e.g., sea level, storm intensity), with updates linked to actual monitored/observed conditions.

- Availability of skills and experience for personnel in climate change and disaster resilience (e.g., risk identific ation, mitigation, planning, response and post-event response).

- Climate preparedness is considered a priority in City planning.

- Integrate c lima te preparedness into zoning, all project and permit review and lic ensing and into the regulations and guidelines that govem these processes. Review and improve waterfront development zoning.

Emergency-related planning -

- Emergency plans are in place (e.g., emergency plan, food security plan, postevent recovery plan, evacuation plan), including coordination for extreme weather event activities within and outside of city, clarity of roles, responsibilities.

- City has adequate capac ity and sup plies for emergencies (e.g., personnel, supplies, equipment, emergency shelters, and vehicle fleet).

- Percentage of people reached by early wa ming systems for hazards and other 
c limate-influenced emergency events.

- Assurance of continuity of all critic al govemment administration functions (e.g., computer systems, data - utilize backup generators) during climate change related events.

- System/plan in place to ensure critic al city workers can reach offic es/destinations during emergency situations.

- Programs a re established to assist businesses with developing business continuity plans; Percentage of vulnerable businesses with continuity of business plan [prepared and implemented plans.

Coordination -

- Govemment structure is in place to coordinate inter- and intra-govemmental c limate prepa redness a c tivities a cross Metro Boston a rea and outside of Boston.

- Convene a regional summit to accelerate regional preparedness planning.

Finances -

- Fina ncial support for climate change ma instrea ming and related initia tives is in place.

- Financial assistance is provided to vulnerable popula tions. 


\section{in}

\section{CLIMATE SCIENCE AND INFORMATION}

Indicator: The degree to which information and data a re available and used to adequately address climate change and related events.

Includes:

- Integration of c limate science and data into decision-ma king;

- Availability of data to decision makers to address climate change and related events; and

- Identific ation of data gaps related to climate change preparedness.

Indicatortype: Enha nce prepa red ness/rea diness; a ddress vulnera bility.

\section{Metrics:}

- Knowledge of hazards that the city faces a nd their likelihoods (e.g., haza rds for sectors identified in \#5 and \#6 to floods, stoms, and other hazards).

- Knowledge of vulnera bility a nd exposure (e.g., vulnera bility of sectors to climate change and related events, scenarios to assess sea level rise/flooding a re completed).

- Data gaps related to needed climate change adaptation information are identified.

- Extent to which climate information is used to inform responses to climate change (e.g., data readily accessible, a vailable, and data a re used to inform adaptation interventions).

- Pa rtnerships esta blished with research universities to a nalyze, test and implement new clima te-preparedness strategies. 


\section{i}

Indicator: The degree to which the public and specific stakeholders are aware of and provide input into preparing for climate change and related events.

Includes:

- Stakeholder/public engagement in planning and preparing for climate change and related events;

- Use of stakeholder/public input in policymaking; and

- Stakeholder/public access to information (e.g., meetings, education materials, networks, schools).

Indicatortype: Enhance preparedness/readiness.

\section{Metrics:}

- Education and a wareness materia ls/messa ging available to public (e.g., website, number of meetings/tra inings held, school c uric ulum; acc ess to stom/huricane preparedness kits).

- Awa reness of public, property owners and tena nts to their individual vulnerabilities related to clima te change (e.g., percent of at risk households holding flood insurance polic ies, number of people at meetings); participation of stakeholders/public in pre-event and event response activities.

- Communities exhibit social connectedness a nd neighborhood cohesion.

- Qua lity of stakeholder engagement in decision-ma king to a ddress climate change (e.g., public/stakehold er input and up take by decision-makers).

- Create neighborhood-based programs that increase climate preparedness while supporting job training and job creation. 


\section{trin}

\section{PUBLIC HEALTH AND SAFETY}

Indicator: The degree to which Boston residents a re vulnerable to climate-related health risks and have access to needed services and amenities.

Includes:

- Climate-related deaths (heat)/illnesses/disea se; and

- Access to critical servic es (e.g., health centers) [c ritical service infrastruc ture is addressed in Public/Private Building and Utilities Indicator].

Indicatortype: Enhance prepa red ness/rea diness; a dd ress vulnera bility.

\section{Metrics:}

- Actions are taken by City to help people (especially vulnerable populations) better cope with climate change.

o Access to critic al servic es (e.g., hospitals, fire departments), cooling centers, and shelters reliable during extreme events, especially for vulnerable populations.

- Fina ncial and technical assista nce for improving people's ability to cope with climate change.

- Number of disea se outb reaks and climate-related illnesses, and prevention measures included in ongoing health programs. 


\section{NATURAL RESOURCES AND COASTAL INFRASTRUCTURE}

Indicator: The degree to which natural ecosystems in Greater Boston a re able to withstand impacts of climate change and related events. Green/gray infrastructure is expanded to address climate vulnerabilities. Protec tive infrastruc ture (e.g., ecosystem components and coastal infrastruc ture - dikes, levees and sea walls) exist and are a dequate to protect aga inst c limate-related events and risks.

Includes:

- Resource management measures-Green/gray infra structure;

- Ec osystem components, parks, trees, shorelines and coastal habitats; and

- Man-made coastal infrastructure (e.g., dikes, levees a nd sea walls).

Indicatortype: Enhance preparedness/readiness; a ddress vulnera bility.

\section{Metrics:}

- Effective resource management measures are implemented, including:

- Green/gray infrastructure and other measures are used as valuable tools in climate preparedness to help reduce the effects of urban heat island, sea level rise, and stom frequency.

o Legisla tive and regulatory means of enhancing requirements for green/gray infrastructure are strengthened and expanded.

- Ec osystem components a re spec ific ally identified and ma naged as critical assets to disaster resilience.

o Awa reness of role of ec osystem components in the city's disa ster resilience.

o Extent and condition of ecosystem components (e.g., coa stal habitats, shorelines, adjacent shore a reas, tree canopy, parks, open space).

o Parks, trees and ecosystem components a re used as valuable tools in climate preparedness to help reduce the effects of urban heat island, sea level rise, and storm frequency.

o Identified conservation mea sures for c limate change resiliency of natural resourcesand ecosystems are being implemented (e.g., land and water protection - amount and type of land cover preserved asopen space, regulation changes, targeted public funding, enhanced monitoring, tree planting, invasive species removal).

- Adequacy of both man-made and natural coastal infrastructure in protecting a ga inst clima te change and rela ted events (e.g., dikes, ecosystem components providing protection, levees, flood bariers, sea walls). 


\section{PUBLIC AND PRIVATE BUILDINGS AND UTILITIES}

Indicator: The degree to which public/priva te build ings and utilities are a dequately prepared to withstand climate change and climate-related events.

Includes extent, condition, and reliability of the following sectors:

- Buildings and infrastruc ture including:
a. Commercial
b. Residential
c. Govemment
d. Critic al facilities (e.g., EMS, fire, police, hospita ls)
e. Education
f. Historic al sites and distric ts

- Utilities including:
a. Transportation - Roa ds, tunnels, a imports, rail, MBTA, bridges, ports
b. Water
c. Stormwater and sewer
d. Telecommunic ations
e. Elec tricity and energy

Indicator type: Enha nce prepa redness/rea diness; a d dress vulnera bility.

\section{Metrics:}

- Vulnerable buildings/infrastruc ture and utilities have been identified and prioritized (see Indicator for C limate Science and Information).

- For each sector, adaptation measures and capacity a re in place to systematic ally reduce current and future risks to acceptable levels for existing build ings and utility infra struc ture. For example:

Buildings:

o Percent of buildings identified as vulnerable (e.g., in 2013 Clima te Rea dy Boston) implementing adaptation stra tegies (e.g., high-risk flood zone buildings a re elevated).

- Struc tural sa fety and disa ster resilience of build ings a re a dequate (e.g., prepared for climate change).

- Small-scale resiliency interventions and pilots a re established in partic ula rly vulnerable a reas.

Utilities:

- Adaptation measures are being implemented to reduce vulnerability of identified "at-risk" utility structures (e.g., elevation of Deer Isla nd). Some specific examplescould include [note, these examples are not comprehensive]:

a. Transportation - Elevation of high-risk flood zone public transportation stops.

b. Water- Water utilities have back-up generators to a void power loss. 
c. Stomwater and sewer- Water absomtion plans for neighborhoods a re created and implemented.

d. Telecommunic ations- Existence and ma intenance of back-up and stand-by communic a tions systems.

e. Electric ity and energy - Existence and maintenance of back-up and stand-by power systems.

- Percentage of new development/utility infrastructure designed to withstand climate change.

o Percentage of new build ings and utility infrastructure incorporating c limate preparedness measures into building design.

- Modific ations to building codes are identified in accordance with best practices in building resiliency (work with commonwealth, insurance and finance sectors, and property owners); and a pplic ation of building codes.

o Percentage of new build ings and utility infrastructure constructed in highrisk flood zones. 


\section{Conclusion \& Next Steps}

The draft indicators framework presented in this report should serve as a good starting point for the City as it begins implementing the 2014 CAP Update, and specific ally as CAP Action 2.32 is addressed by the City and the City's climate action partners. Unfortunately, there does not yet exist in the United States any standardized approach for communities to follow in developing a holistic CCA indic ator program. Given Boston's considerable leadership to address mitigation and adaptation to clima te change, the $C$ ity is well positioned to help advance the development of such approaches.

There are numerous local, state, Federal, and intemational efforts currently underway that address the development of indices or indic ators of community resilience and preparedness-- some of which are desc ribed in Appendix 1 . As the City and its Climate Action partners move forward with developing an indicator system for the City of Boston, a number of initiatives occuming through President Obama's Climate Action Plan should also be consulted to inform these efforts moving forward. These programs include the U.S. Climate Resilience Toolkit, the Climate Data Initiative, Climate Ready Water Utilities, and the Council and Task Force on Climate Preparedness and Resilience. In addition, there is a wealth of community level preparedness and resilience indic a tor tools being developed for disaster and/or c limate change that can help further inform these efforts. For example, The United Nations Offic e for Disaster Risk Reduction's Disa ster Resilience Scorecard for Cities, desc ribed in Appendix 1, is an exc ellent model that could be very helpful to Boston's CCA Indic a tor development.

In spring 2015, SeaPlan and ERG, Inc. will be completing a project for NOAA's Coastal Servic es Center to develop a comprehensive evaluation of community resilience indicators in the U.S. and develop tools that will be useful to communities that are developing resilience indic ators and evaluation frameworks. The products of this work should be very helpful to Boston as it begins to implement Action \# 2.32 of the CAP. 


\section{References}

Ayers, J ., S. Anderson, S. Pradhan, and T. Rossing, 2012. Partic ipatory Monitoring, Evaluation, Reflection and Leaming for Community-based Adaptation: A Manual for Local Practitioners CARE and IIED, J une. Available from:

http://www.carec lima techange.org/files/ada ptation/CARE_PMERL_Manual_2012.pdf

Bours, D., C McGinn, and P. Pringle, 2014. Guidance note 1: Twelve rea sons why climate change a daptation $M \& E$ is challenging. SEA Change and UKCIP, J a nuary. Availa ble from: http://www.seachangecop.org/node/2728.

Bours, D., C. McGinn, and P. Pringle, 2014. Guidance note 2: Selecting indic ators for climate change adaptation programming. SEA Change and UKCIP, J anuary. Ava ilable from: http://www.seachangecop.org/node/2806.

Bours, D., C. McGinn, and P. Pringle, 2014. Guidance note 3: Theory of Change approach to climate change adaptation programming. SEA Change and UKCIP, February. Available from: http://www.seachangecop.org/node/2933.

Bours, D. C. McGinn, P. Pringle, 2014. Monitoring \& Evaluation for Climate Change Adaptation and Resilience: A Synthesis of Tools, Frameworks and Approaches. SEA Change and UKCIP, May. Available from: http://www.seachangecop.org/node/2588.

The City of New York, 2014. Pla NYC Progress Report 2014. Mayor's Offic e of Long-Term Planning and Susta ina bility. Available from:

http:// www.nyc.gov/html/pla nyc/html/public ations/public a tions.shtml.

Commonwealth of Australia, 2013. The Climate Adaptation Outlook: A Proposed National Adaptation Assessment Framework. Department of Industry, Innovation, Climate Change, Science, Research, and Tertiary Education, J une. Ava ilable from: http://www.environment.gov.au/clima te-change/adaptation.

Department of Homela nd Security, 2008. DHS Risk Lexic on. Risk Steening Committee, Wa shington, DC. Available from: http://www.dhs.gov/xlibrary/assets/dhs risk lexic on.pdf.

Ehler, C.N. 2014. A Guide to Evaluating Marine Spatial Plans. UNESCO IOC, Paris.

Harley, M.L and J . van Minnen, 2009. Development of Adaptation Indic ators. ETC/ACC Technic al Paper. ETC/ACC, December.

Harley, M. L. Horrocks, N. Hodgson (AEA), and J . van Minnen (PBL), 2008. Climate Change Vulnerability and Ada ptation Indic ators. ETC/ACC Technical Paper 2008/9. European Topic Centre on Air and Climate Change (ETC/ACC), December. Available from: http://acm.eionet.europa.eu/docs/ETCACC_TP_2008_9_CCvuln_adapt_indic ators.pdf.

Intemational Institute for Environment and Development (IIED), 2013. Tracking Adaptation and Measuring Development (TAMD) in Ghana, Kenya, Mozambique, Nepal, Pakistan: Metaa na lysis Find ings from Appra isal and Design Phase. Ava ilable from:

http://pubs.iied.org/pdfs/G03631.pdf.

Intemational Institute for Environment and Development (IIED), 2014. Tra c king a da ptation a nd 
measuring development (TAMD) framework. Updated 28 Oct. 2014. Available from: http://www.iied.org/tra cking-a da ptation-mea suring-development-ta md-fra mework.

Mayor Martin J. Walsh, 2014. Climate preparedness. Greenovate Boston: 2014 Climate Action Plan Update. City of Boston, Boston, MA. Available from:

http://www.cityofboston.gov/climate/bostonsplan/.

National Resea rch Counc il, 2012. Disa ster Resilience: A National Imperative. National Aca demies Press, Wa shington, D.C.

Newman, J ., M. Springer, T. Sheehan, J . Gravelin, L. Trouche, S. Sla ughter and A. Wilson, 2013. Building Resilience in Boston: "Best Practices" for Climate Change Adaptation and Resilience for Existing Build ings. Linnean Solutions, built environment coalition, and Resilient Design Institute.

Notre Dame Global Adaptation Index (ND-GAIN), 2013. Detailed methodology report. Environmental Change Initiative, Notre Dame, IN. Ava ilable from: http://www3.nd.edu/ nchawla/methodology.pdf.

Olivier, J ., T. Leiter, and J . Linke, 2012. Ada ptation Made to Mea sure: A G uidebook to the Design and Results-based Monitoring of Climate Change Adaptation Projects. Deutsche Gesellsc haft für Intemationale Zusa mmena rbeit (GIZ), J uly.

Pa my, M.L., O.F. Canziani, J .P. Pa lutikof, P.J . van der Linden and C.E. Hanson, (Eds.). Appendix 1. Glossary A-D, G lossary E-O, and G lossary P-Z 2007. Contribution of Working Group II to the Fourth Assessment Report of the Intergovemmental Pa nel on Climate Change. Cambridge University Press, Cambridge, UK. Ava ila ble from: www.ipcc.ch.

resilience. 2015. In Meriam-Webster.com. Available from: http://www.memiamwebster.com/dictiona ry/resilience.

Sc ully, C.C., 2012. San Francisco's climate and health program: Progress and lessons leamed. San Franc isc o Department of Public Health, Center for Disease Control and Prevention (CDC).

SF Environment, 2014. Adaptation. Available from: http://sfenvironment.org/article/climatechange/adaptation.

Sniffer, 2012. Climate Change Adaptation-Related Indicators. ER23 Final Report, J uly. Sniffer, Edinburgh. Available from: www.sniffer.org.uk.

Speaman, M. and H. McGray, 2011. Making Adaptation Count: Conceptsand Optionsfor Monitoring and Evaluation of Climate Change Adaptation. GIZ, August.

Spector, C. and L. Bamberger, 2013. Climate Ready Boston: Munic ipal Vulnera bility to Climate Change. Climate Preparedness Task Force, City of Boston, October. Ava ilable from: http://www.c ityofboston.gov/clima te/a daptation/.

STAR Communities, 2014. STAR Community Rating System 1.1. Ava ila ble from: https:// www.sta rc ommunities.org/uploads/rating-system.pdf. 
United States Environmental Protection Agency (USEPA). 2014. Climate Change: Ba sic Information. Updated March 18, 2014. Available from:

www.epa.gov/climatechange/basics/.

United States Environmental Protection Agency Region 3. 2014. How We Use Data in the MidAtlantic Region: Environmental Indic a tors. Philadelphia: Office of Environmental Information and Analysis, US EPA Region 3. Available from: www.epa.gov/reg3esd 1/data/indic ators.htm. Last updated 10/23/14.

United Nations Fra mework Convention on Climate Change (UNFCCC). 2010. Synthesis Report on Efforts Undertaken to Monitor and Evaluate the Implementation of Adaptation Projects, Polic ies and Programmesand the Costs and Effectiveness of Completed Projects, Polic ies and Programmes, and Views on Lessons Leamed, Good Practices, Gapsand Needs. , 32nd session of the Subsidiary Body for Sc ientific and Technological Advice, May 31-J une 9, Bonne.

United Nations Office for Disaster Risk Reduction (UNISDR), 2014, Disa ster Resilience Sc orec ard for Cities, Working Document, prepared by AECOM and IBM. Available from: http://www.unisdr.org/2014/c ampaign-cities/Resilience\%20Sc oreca rd\%20V1.5.pdf.

Villa nueva, P. S., 2010. Leaming to ADAPT: Monitoring and evaluation a pproaches in climate change adaptation and disaster risk reduction - Challenges, gaps and ways forwa rd. SCR Disc ussion Pa per 9. UK Institute of Development Studies, Plan Intema tiona I and Christian Aid. Available from: http://www.ids.ac.uk/public ations.

Wilson, A. 2013. RDI's Resilient Design Princ iples. Resilient Design Institute, Brattleboro, VT. Ava ila ble from: http://www.resilientdesign.org/rdis-resilient-design-principles-need-yourfeedback/. 


\section{Appendix 1: Literature Review}

This section summarizes the literature we reviewed and key points to inform this project. The team divided the literature into the following subsections:

I. Guidebooks, Toolkits, and Reference Materia ls for Developing a CCA Indic ators Framework

II. CCA Programs, Rating Systems, and Indic es

III. Climate Change Documents Specific to Boston

See more details on the specific documents we reviewed below, as well as a summary of key points.

\section{Guidebooks, Toolkits, and Reference Materials for Developing a CCA Indicators Framework}

As noted by Bours and McGinn, et al. (2014) "there has recently been a proliferation of CCAR M\&E initiatives, guidelines, and frameworks." 1 Below is a brief summary of guidebooks, toolkits and reference materials for developing a CCA Indic a tors Framework that we found most useful for Boston, organized by the agency that developed the material(s). Additional details a re also provided on each material, including an overview of the material's purpose and its potential applicability to Boston.

1. SEA Change and United Kingdom Climate Impacts Programme (UKC IP) SEA Change is a free, online Community of Practice on monitoring and evaluation of climate change in Asia and other locations. ${ }^{2}$ Their goal is to develop a culture of high quality and rigorous M\&E frameworks, approaches and methodologies. UKCIP, based at the Environmental Change Institute at the University of Oxford, helps organizations, sectors and govemments adapt to climate change by providing, advice, support and practice-based research. Their work emphasizes scientific research, polic y making and adaptation practices. UKCIP and SEA Change developed a number of guidebooks and reference materia ls for developing a CCA indic ators framework, including:

- "Monitoring \& evaluation for climate change adaptation and resilience: A synthesis of tools, frameworks and approaches" (2014)

This d oc ument provides a comprehensive review of existing monitoring and evaluation toolkits, frameworks and a pproaches. SEA Change developed this doc ument for polic y-makers, researc hers, and communities such as Boston to compare various ap proaches and identify which materials would be most useful to them. ${ }^{3}$ The SeaPlan team reviewed the approaches described in this doc ument and summarized a number of them below.

\footnotetext{
1Bours, D., C. McGinn, and P. Pringle, 2014, Monitoring \& Evaluation for Climate Change Adaptation and Resilience: A Synthesis of Tools, Frameworks and Approaches: 12, SEA Change and UKC IP, availa ble from: http://www.seachangecop.org/node/2588

$2 \mathrm{lbid}, 2$.

$3 \mathrm{lbid}$.
} 
- Guidance Note 1: "Twelve reasons why clima te change adaptation M\&E is challenging" (2014)

This guidebook outlines the challenges and complexities that are unique to implementing climate change adaptation $M \& E$ programs. It also provides strategies for dealing with these challenges and can serve as a guide for Boston as it develops its own CCA indic a tor fra mework.

- Guidance Note 2: "Selecting Indic a tors for climate change adaptation programming" (2014)

This guidebook provides various a pproaches for selecting CCA indic ators and outlines important indic ator criteria. It also disc usses the advantages and disadvantages of using process versus outc ome based indic a tors.

- Guidance Note 3: "Theory of Change approach to climate change adaptation programming" (2014)

This guidebook outlines Theory of Change, a critic al thinking approach to program design, monitoring, and evaluation that has been influential in intemational development. ${ }^{4}$ It can be applied to a wide va riety of development issues including conflict resolution, gender inequality and climate change. Theory of Change provides a process that engages stakeholders in identifying and achieving long-term climate adaptation goals, making it a possible approach for Boston.

2. Deutsche Gesellschaft für Intemationale Zusa mmenarbeit ( $G$ IZ) GIZassists the German Govemment in achieving its objectives in the field of intemational cooperation for susta ina ble development. ${ }^{5} \mathrm{GIS}$ develops solutions for a variety of development issues including climate change mitigation and adaptation, and has developed the following guides for the German govemment and other audiences:

- Making a daptation count (step-by-step guide) (2011)

This guide provides a fra mework for developing $M \& E$ systems that tracks the progress of a daptation initiatives. It includes a step by step process for selecting adaptation indic ators. It a lso disc usses lessons lea med from other adaptation efforts that could prove useful as Boston develops its own indic ator program. ${ }^{6}$

- Adaptation made to measure (2012)

This guide explains a five-step approach to designing an adaptation project, results framework, and monitoring system. It includes examples where this approach has been applied in India, which may be applic able to Boston. ${ }^{7}$

\footnotetext{
${ }^{4}$ Bours, D., C. McGinn, and P. Pringle, 2014, Guidance note 3: Theory of Change approach to climate change adaptation programming, SEA Change and UKCIP, February, a vailable from:

http://www.seachangecop.org/node/2933.

${ }^{5}$ Deutsc he Gesellsc haft für Intema tiona le Zusa mmena rbeit (GIZ) G mbH, 2014, Profile: Broad-based expertise for sustainable development, available from: https://www.giz.de/en/aboutgiz/profile.html. ${ }^{6}$ Spearman, M. and H. McGray, 2011, Making Adaptation Count: Concepts and Options for Monitoring and Evaluation of Climate Change Adaptation, GIZ, August.

7 Olivier, J., T. Leiter and J . Linke, 2012, Adaptation Made to Measure: A Guidebook to the Design and Results-based Monitoring of Climate Change Adaptation Projects, GIZ, J uly.
} 
3. European Topic Centre on Air and Climate Change (ETC/ACM)

The ETC/ACM is a consortium of 14 European orga nizations led by Netherlands Institute for Public Health and the Environment (RIVM). These organizations provide support to the European Environment Agency (EEA) through reporting on European environmental policy progress. Areas of foc us include air quality and climate change ${ }^{8}$, and they developed the following documents related to climate change adaptation:

- Climate Change Vulnerability and Adaptation Indic ators (2008)

This tec hnic al paper disc usses funda mental concepts surround ing the development of a daptation indic ators. The fra mework foc uses on developing process-based and outcome-based indicators, which could be applic able to Boston. ${ }^{9}$

- Development of Adaptation Indicators (2009)

This tec hnic al report provides a framework for developing a daptation indic ators, and foc uses specific ally on applying the fra mework to the vulnerability of biodiversity to climate change. ${ }^{10}$

\section{Leaming to ADAPT}

The Lea ming to ADAPT report (2012) provides a potential a pproach for establishing an $M \& E$ program for c limate a daptation. It includes princ iples of successful a da ptation indic a tor and disc usses existing approaches and challenges. The report a lso poses questions to consider when setting up $M \& E$ adaptation programs that could be a pplic able to Boston, including ${ }^{11}$ :

- To what extent a re clima te change adaptation, disaster risk management and development integrated across sectors and scales?

- What processes are in place to support govemments, communities and other sta keholders to effectively manage the unc erta inties rela ted to climate change?

- How are findings from scenario planning exercises and climate-sensitive vulnera bility a ssessments being integrated into existing strategies?

5. Global Environment Facility Climate-Evaluation Community of Practice Climate-Evaluation (C limate-Eval) is an online community of practice hosted by the G lobal Environment Fac ility Independent Evaluation Office (GEF IEO) in Washington, D.C. The community of practice's goal is to esta blish evaluation standards, support capacity development, and share good practices in evaluations of climate change and development ${ }^{12}$. It has published the following guides:

- Tracking progress for effective action: A fra mework for monitoring and evaluation adaptation to climate change (2011)

\footnotetext{
${ }^{8}$ European Topic Centre for Air Pollution and Climate Change Mitigation (ETC/ACC), 2014, European Environment Agency.

9 Harley, M., L. Horrocks, and N. Hodgson et al., 2008, Climate Change Vulnerability and Adaptation Indic ators, ETC/ACC Tec hnic al Paper 2008/9, ETC/ACC, December, 10-11.

10 Harley, M.L. and J . van Minnen, 2009, Development of Adaptation Indic ators, ETC/ACC Technic al Paper, December.

11 Villanueva, P.S., 2010, Leaming to ADAPT: Monitoring and Evaluation Approaches in Climate Change Ada ptation and Disaster Risk Reduction - Challenges, Gaps and Ways Forward, SCR Disc ussion Pa per 9, UK Institute of Development Studies, Plan Intemational and Christian Aid, September, 2.

12 Climate-Eval, 2014, About Climate-Eval, a vailable from: https:// www.c limate-eval.org/a bout
} 
This report outlines a framework for creating a monitoring and evaluation program for climate change adaptation. It provides a six step guide to establishing an a daptation program, disc usses key adaptation challenges and provides a list of sample indic a tors that could be applic able to Boston ${ }^{13}$. See Appendix 7.

- Climate change adaptation monitoring and assessment tool (AMAT) (2014)

The Adaptation Monitoring and Assessment Tool (AMAT) was released with the goal of inc reasing developing countries' resilience to climate change by integrating adaptation practices into development policies and programs. This tool conta ins a spreadsheet with a list of indic a tors to measure a country's progress towards reducing climate change vulnerability. While the tool is geared towards developing countries, aspects may be useful for Boston ${ }^{14}$.

6. Cooperative for Assistance and Relief Everywhere (CARE) and Intema tional Institute for Environment and Development (IIED)

CARE is a huma nita rian organization that focuses on a variety of intemational issues including clima te change. Intema tional Institute for Environment and Development (IIED) is a n intema tional development and environmental polic y research orga nization based in the UK that have contributed to multiple intemational polic y processes and fra meworks, including the Intergovemmental Panel on Climate Change (IPCC). IIED also created the Tracking Adaptation Measuring Development framework summarized in the body of this report. Care and IIED developed the following manual:

- Partic ipatory monitoring, eva luation, reflection and lea ming (PMERL) project for community-based adaptation (2012)

This ma nual wascreated to support adaptive decision-making in vulnerable communities. It is intended to be an open-source methodology for vulnerable communities to inform climate adaptation planning and implementation. It describes key concepts for community-based adaptation, outlines a strategy for implementing PMERL strategies, and provides tools and methods for PMERL development. ${ }^{15}$

\section{Adaptation Fund}

The Adaptation Fund was established to finance concrete adaptation projects and programs in vulnerable developing countries that are parties to the Kyoto Protocol. 16 The fund has dedicated more than $\$ 265$ million to increase climate resilience in 44 countries a round the world ${ }^{17}$, and developed the following report:

- Results fra mework and baseline guidance: Project-level (2011)

This report provides guidance for developing a results framework for a daptation projects. It describes the phases of project design and performance assessment,

\footnotetext{
13 Sanahuja, H.E., 2011, A Framework for Monitoring and Evaluating Adaptation to Climate Change, Climate-Eval, August.

14 G lobal Environment Fac ility, 2014, LDCF/SSCF Adaptation Monitoring and Assessment Tool (AMAT).

15 Ayers, J., S. Anderson, S. Pra dhan, and T. Rossing, 2012, Pa rtic ipatory Monitoring, Evaluation, Reflection and Leaming for Community-based Adaptation, CARE and IIED, J une.

16 The Kyoto Protocol isan intemational agreement which sets intemationally binding greenhouse gas emission reduction ta rgets for partic ipating countries

17 The Adaptation Fund, 2014, About the Adaptation Fund, a vailable from: https://www.adaptationfund.org/about.
} 
and provides advice on selecting indic ators, setting targets, and collecting data. Although it is designed specific ally for the countries associated with the Adaptation Fund, its overall framework may be applicable to Boston ${ }^{18}$.

8. Climate Investment Funds (CIF)

CIF provides climate change mitigation resources to developing and middle income countries. Their funding supports projects related to clean technology and energy, forests, and climate change resilience ${ }^{19}$, and they developed the following toolkit:

- $\quad$ PPCR (Pilot Program for Clima te Resilience) Monitoring and Reporting Toolkit (2014)

This toolkit provides an overview of the 5 PPCR indic ators. The five ind ic ators, which may be applicable to Boston, include ${ }^{20}$ :

1) Degree of integration of climate change into planning

2) Evidence of strengthened govemment capacity and coordination mecha nism to mainstream clima te resilience

3) Quality and extent to which c lima te responsive instruments/investment models are developed and tested

4) Extent to which vulnerable households, communities, businesses a nd public sector servic es use improved PPCR supported tools, instruments, strategies and activities to respond to climate variability or climate change

5) Number of people supported by the PPC R to cope with the effects of climate change

\section{CCA Programs, Rating Systems and Indices}

We also conducted a literature review of CCA programs, rating systems and indices from a round the world. In total, we researched 12 different programs (Appendix 2), including programs with a daptation plans for individual c ities such as New York City and San Francisco, as well as national a daptation plans for Australia, Germany and other countries. We also looked into intemational programs that evaluate and rank countries, such as the ND-Gain index, DARA's C lima te Vulnera bility Index and others. Reviewing the methodology of these programscan provide insight into developing a set of indicators for Boston. While many of programs cannot be directly applied to Boston, they offer guidelines for selecting indic a tors.

In general, the programs that seemed to be the most successful began by establishing concrete goals and selected easily mea surable indicators that were relevant to these goals. Some programs a re well established, while others a re still in the process of establishing adaptation goals and developing indic ators.

Below is a summary of five different ind ic ator programs which were selected from the literature review based on their strong methodology and the applicability of their indicators to Boston. For a complete list of programs, rating systems and ind ic es reviewed, see Appendix 1.

18 The Adaptation Fund, 2011, Results Framework and Baseline Guidance, Project-level.

${ }^{19}$ Climate Investment Funds, 2015, About the Climate Investment Funds, available from: www.c limateinvestmentfunds.org/c if/a boutus.

${ }^{20}$ Climate Investment Funds, 2013-4, PPCR Results Framework and Monitoring and Reporting Toolkit, $2 .$. 


\section{STAR Community Rating System}

\section{Oveniew}

The overall goal of this project is to create a susta inability fra mework that could be implemented in communities a cross the country. The STAR fra mework can be used voluntarily by any community to track their progress towa rds susta ina bility goals, such as reduc ing greenhouse gas emissions or improving water and energy effic iency. The STAR Community Rating System is flexible in that it gives local leaders the choice of selecting different ta rgets based on their own community's needs.

To create the framework, resea rchers selected community objectives under the categories: Built Environment, Clima te and Energy, Economy and jobs, Education, Arts and Community, Equity and Empowement, Health and Sa fety, and Natural Systems. They identified between 5 and 7 objectives for each category and selected two types of ind ic a tors for each objec tive. These indic ators include:

- Community level outc omes- mea surable indic a tors that demonstrate a community's susta ina bility progress

- Local actions- the steps taken toward the community level outc omes such as concrete plans or funds. ${ }^{21}$

Communities rec eive a rating based on how many outcomes and actions they achieve.

\section{Applicability to Boston}

The STAR fra mework is c urently the only ind ic ator program geared towa rds cities such as Boston. Under STAR's C limate and Energy objectives, there are specific local actions related to climate change adaptation that may be applic able to Boston ${ }^{22}$ :

1. Adopt a climate change adaptation plan

2. Require that intemal decisions by local govemment departments use the most current climate science and that staff monitor climate change impacts

3. Develop a committee that inc ludes c limate scientists, a djacent jurisdic tions, regional coalitions, state and federal agencies, and/or non-govemmental organiza tions for the purpose of understanding and addressing shared vulnerabilities

4. Create an education and outreach campaign to engage citizens and businesses in c limate change vulnerability reduction efforts

5. Adopt zoning code, building code, or other legally bind ing regulations that address future climate change threats

6. Create or enhance programs and servic es that specific ally help address climate change threats

7. Enforce regulations or offer inc entives to encoura ge residents and businesses to shift behaviors to prepare for future climate change impacts

Table 1 below displays Sea Plan's a nalysis of Boston's progress toward s each of these objectives

Table 1. Progress of the City of Boston towards STAR Climate and Energy Objectives

STAR Actions

21 STAR Fra mework, 2014, 9.

22 Ibid., 35-6. 


\begin{tabular}{|c|c|}
\hline 1.Adopt a climate change adaptation plan & $\begin{array}{l}\text { a comprehensive climate change } \\
\text { prepared ness plan. }\end{array}$ \\
\hline $\begin{array}{l}\text { 2. Require that intemal decisions by local govemment } \\
\text { departments use the most current climate science and that } \\
\text { staff monitor climate change impacts }\end{array}$ & $\begin{array}{l}\text { - UnderMA State law, state agenciesare } \\
\text { required to take c limate change threats into } \\
\text { account for all projects. }\end{array}$ \\
\hline $\begin{array}{l}\text { 3. Develop a committee that includes climate scientists, } \\
\text { adjacent jurisdictions, regional coa litions, state and federal } \\
\text { a gencies, a nd/or non-govemmental organizations for the } \\
\text { purpose of understanding and addressing shared } \\
\text { vulnerabilities }\end{array}$ & $\begin{array}{l}\text { - In } 2013 \text {, The Boston Green Ribbon Commission } \\
\text { was created and tasked with providing } \\
\text { advice on c limate action plan updates. } \\
\text { The commission includes a Climate } \\
\text { Preparedness working group that is } \\
\text { considening c limate vulnera bilities. }\end{array}$ \\
\hline $\begin{array}{l}\text { 4. Create an education and outreach campaign to engage } \\
\text { citizens and businesses in climate change vulnerability } \\
\text { reduction efforts }\end{array}$ & $\begin{array}{l}\text { - Boston has launched a communic ations } \\
\text { campaign to engage citizens in the } 2014 \text { CAP } \\
\text { update process } \\
\text { Though more mitigation focused, } \\
\text { communic ations program Greenovate Boston } \\
\text { also exists to engage citizens and change } \\
\text { public behavior }\end{array}$ \\
\hline $\begin{array}{l}\text { 5. Adopt zoning code, build ing code, or other legally binding } \\
\text { regulations that address future climate change threats }\end{array}$ & $\begin{array}{l}\text { - Under article } 80 \text { of the Boston Zoning Code, } \\
\text { the Boston Redevelopment Authority (BRA) } \\
\text { requires project developers to a nalyze } \\
\text { potential effects of c limate change such as } \\
\text { flooding } \\
\text { In addition, The Boston Conservation } \\
\text { Commission hasproposed a Local Wetlands } \\
\text { Ordinance for Boston }\end{array}$ \\
\hline $\begin{array}{l}\text { 6. Create or enhance programs and senvicesthat specifically } \\
\text { help address climate change threats }\end{array}$ & $\begin{array}{l}\text { - Boston created the Complete Streets } \\
\text { program, which established guidelines for } \\
\text { new streets. Complete Streets has a wide } \\
\text { variety of sustainability goals inc luding } \\
\text { reducing flooding. }\end{array}$ \\
\hline $\begin{array}{l}\text { 7. Enforce regulations or offer incentives to encourage } \\
\text { residents and businesses to shift behaviors to prepare for future } \\
\text { climate change impacts }\end{array}$ & $\begin{array}{l}\text { N/A - Unable to find via literature review; } \\
\text { consult with City }\end{array}$ \\
\hline $\begin{array}{l}\text { 8. Improve facilities throughout the community to be better } \\
\text { prepared forclimate change threats }\end{array}$ & $\begin{array}{l}\text { - The Boston Society of Architec ts published } \\
\text { Building Resilience in Boston, a report that } \\
\text { includes best practic es and } \\
\text { recommendations for improving Boston's } \\
\text { build ings. }\end{array}$ \\
\hline
\end{tabular}

\section{New York City (NYC) and San Francisco}

\section{Oveniew}

NYC - NYC has developed Pla NYC, which is a n effort to address NYC's long-tem challenges, including changes in populations, economic conditions, infrastructure, and climate. The Plan sets forth a broad range of goa ls a cross the following a reas: Housing, Parks and Public Space, Brownfields, Waterways, Water Supply, Transportation, Energy, Air Quality and Climate Change.

San Francisco - San Francisco created a working group, AdaptSF, to address the city's ma in climate change threats, which include sea level rise, flooding, and extreme heat events. The group has not selected climate adaptation indicators, but it has completed several different adaptation initiatives including a study on sea level rise 
impacts on the Port of San Fra nc isc o and a n a ssessment of public health impacts from extreme heat. Currently, the group is working on the following initia tives ${ }^{23}$ :

- integrating sea level rise and energy assurance planning into San Francisco's

Capital Planning and Hazard and Mitigation plans

- communicating public health impacts to San Franciscans

- communicating flood risk and opportunities for home owners to invest in flood insurance

- evaluating San Francisco's sea wall and impacts of sea level rise on the Embarcadero and Financial District

- evaluating potential sea level rise climate change impacts on San Francisco Intemational Aiport

- developing a plan for transit impacts

\section{Applicability to Boston}

While San Francisc o has not developed a set of clima te change adaptation indicators, they have developed a key set of climate change priorities that could be applicable to Boston, including sea level rise and flooding, extreme heat events, and natural environment presenvation. ${ }^{24}$

PlaNYC may be more directly applic able to Boston, as they have developed recommended metric selated to coastal resilience and adaptation. See metric sin Table 2. below:

Table 2. plaNYC resiliency and a daptation metric s. 25

\begin{tabular}{|c|c|}
\hline Category & Metric \\
\hline \multirow[t]{3}{*}{ Coastal Protection } & Federal dollars secured for coastal protection projects \\
\hline & Number of build ings with reduced coastal risk due to coastal protec tion projects \\
\hline & Number of cubic yards of beach sand nourishment \\
\hline \multirow[t]{2}{*}{ Buildings } & Number of buildings implementing Core Flood Resiliency Measures \\
\hline & $\begin{array}{l}\text { Number of square feet of residential and non-residential build ings implementing } \\
\text { Core Flood resiliency mea sures }\end{array}$ \\
\hline \multirow[t]{2}{*}{ Insurance } & Percent of residences in 100-yea r floodplain purcha sing flood insurance \\
\hline & Average premium paid for National Flood Insurance Program (NFIP) policies \\
\hline \multirow[t]{2}{*}{ Utilities } & Percent of residences in 100-year floodplain purcha sing flood insurance \\
\hline & Average premium paid for National Flood Insurance Program (NFIP) policies \\
\hline \multirow[t]{3}{*}{ Liquid Fuels } & Percent of gas stations with quic k-c onnects for generators \\
\hline & $\begin{array}{l}\text { Percent of regional fuel terminal capacity in the 100-year floodpla in hardened } \\
\text { against a } 100 \text {-year flood }\end{array}$ \\
\hline & $\begin{array}{l}\text { Percent of regional refining capacity in the } 100 \text {-year floodplain hardened } \\
\text { against a 100-year flood }\end{array}$ \\
\hline
\end{tabular}

${ }^{23}$ San Francisco Department of the Environment, 2013, San Francisco Climate Action Strategy.

24 SF Environment, 2014, Adaptation, http://sfenvironment.org/article/climate-change/a daptation.

25 The City of New York, 2014, plaNYC Progress Report 2014, 89, a vaila ble from:

http://www.nyc.gov/html/planyc/html/public ations/public a tions.shtml. 


\begin{tabular}{|c|c|}
\hline Healthc are & Percent of hospital beds in 500-year floodpla in meeting resiliency standards \\
\hline & $\begin{array}{l}\text { Percent of beds in nursing homes and a dult c a re facilities in 100-year flood pla in } \\
\text { meeting resiliency requirements }\end{array}$ \\
\hline Telecommunic ations & $\begin{array}{l}\text { Number of critical telec ommunic ations fac ilities implementing Core Flood } \\
\text { Resiliency Measures }\end{array}$ \\
\hline Transportation & Number of lane-miles reconstructed or resurfaced \\
\hline & $\begin{array}{l}\text { Percent of New York C ity tra nsporta tion assets ad apted for c limate change } \\
\text { resiliency }\end{array}$ \\
\hline Parks & $\begin{array}{l}\text { Percent of DPR facilities in Sandy inundation zone upgraded for greater } \\
\text { resiliency }\end{array}$ \\
\hline & Number of trees inspected and pruned \\
\hline Waste and Wastewater & $\begin{array}{l}\text { Number of wastewater facilities or assets protected or raised above the 100- } \\
\text { year flood plain }\end{array}$ \\
\hline & Number of right-of-way bioswales constructed \\
\hline & Number of sewer miles built in areas with no or partial sewers \\
\hline & Number of Bluebelt Best Management Practic es (BMPs) \\
\hline & $\begin{array}{l}\text { Percent of water quality sa mples c omplying with Surface Wa ter Treatment Rule } \\
\text { standard for turbidity }\end{array}$ \\
\hline Solid waste & Number of DSNY facilities protected or raised a bove the 100 -year floodplain \\
\hline Food supply & Number of grocery stores with generators or quick connects for generators \\
\hline & Percent of DCAS food proc urement backstopped with more resilient distributors \\
\hline
\end{tabular}

Pla NYC also identified ten susta inability indicators to track conditions and monitor goals (related to topics such as solid waste, a ir quality and climate change). ${ }^{26}$ While Pla NYC notes the importance of climate change adaptation and "increasing the resiliency of our communities, natural systems, and infra struc ture to climate risks", the one susta ina bility ind ic ator related to climate change is more foc used on mitigation than adaptation (a metric to measure "greenhouse gas emissions"). For a complete list of susta ina bility indic a tors, see Appendix 6.

\section{Australia's Proposed National Adaptation Framework Oveniew}

In 2013, the Austra lian Govemment published a climate a daptation outlook report that summanized Australia's preparedness for c limate change and proposed a national adaptation framework which has yet to be adopted. ${ }^{27}$ This proposed adaptation fra mework foc uses on three a reas ${ }^{28}$ :

\footnotetext{
26 The City of New York, 2014, 32-33.

${ }_{27}$ Commonwealth of Australia, 2013, The Climate Adaptation Outlook: A Proposed National Adaptation Assessment Framework.Department of Industry, Innovation, Climate Change, Science, Research, and Tertiary Education, J une, available from: http://www.environment.gov.au/climatechange/adaptation.

28 lbid., 2.
} 
1) Drivers- factors such as resource a lloc ation, c limate risks, and market pressures that influence behavior.

2) Activities- actions taken by the govemment, industry and communities as a result of drivers.

3) Outc omes for c limate risk mana gement, idea lly supporting susta ina ble management of climate change risks in Australia.

\section{Applicability to Boston}

While indic ators for Austra lia have not been put in place, a list has been proposed (See Appendix 7). This list includes indic ators specific ally for managing climate risks in the coastal zone 29 that may be applic able to Boston, including:

- Capacity of planning frameworks to support effective management of clima te risks in the coastal zone

- Number of local govemments considening climate change risks in land use planning

\section{Tracking Adaptation Measuring Development (TAMD)}

\section{Oveniew}

In addition to adaptation programs spec ific to individual cities and countries, indic es have also been established for companing different countries' climate change vulnerability and preparedness. These programs vary in their goals, but they have wellestablished methodologies, aspects of which may be applic able to Boston. The Tracking Adaptation and Measuring Development (TAMD) program developed by the Intemational Institute for Environment and Development (IIED), stood out because of its unique approach. While other programs focus solely on climate adaption, the TAMD fra mework also considers the impacts on climate change adaptation on development. The indicators they selected:

- Have broad applic ability to different countries

- Measure climate change vulnerability to demonstrate the impact of adaptation measures

- Account for social, economic, politic al, cultural and environmental factors

For each indic ator, the IIED created a rubric for evaluating specific countries. There are a specific set of questions associated with each indic ator. A country's overall score can then be calculated based on the 9 indicators.

\section{Applicability to Boston}

The TAMD framework was largely created for developing countries and is still in its pilot phase. However, they selected 9 broad indicators that could be applicable to Boston:

1. Climate Change integration into planning: Assesses the extent to which climate change risks are considered in national and institutional planning.

2. Institutional Coordination for Integration: Evaluates c limate risk management coordination across govemment agencies and other institutions.

3. Budgeting and Finance: Captures the extent to which climate change measures are budgeted for and have financial support 
4. Institutional Knowledge and Capacity: Assesses institutional knowledge of climate change and how it informs a daptation planning

5. Climate Information: Evaluates how new climate information informs adaptation planning

6. Uncerta inty: Assesses the degree to which adapta tion planning addresses future clima te change uncertainty

7. Partic ipation: Evalua tes inclusion of a ll relevant stakeholders vertic ally (a cross d ifferent levels of govemment) and horizonta lly (a cross different sectors).

8. Awareness a mong stakeholders: Mea sures sta keholder a wa reness of climate change issues, risks and responses

9. Vulnerability/Resilience: Evaluates the ability of a population to respond and recover from clima te change

These indic ator categories, as well as the type of information collected on each indicator and framework format (as shown in the hyperlinks a bove), may be useful as we develop indic ators for Boston.

In addition, IIED has enc ountered several challenges in ap plying its fra mework to other countries, which include lack of climate change data and govemment involvement in its pilot countries. ${ }^{30}$ These challenges were specific to developing countries, but should still be considered if a pplying aspects of the TAMD fra mework to Boston.

\section{ND-GAIN Index}

\section{Oveniew}

Similar to TAMD, the ND-Ga in Index, run by Notre Dame University's C limate Change Initiative, is a free open source index that evaluatescountries' climate change readiness and vulnerabilities. The index uses ind ic ators to rank 177 countries. In 2012, the United States is ranked \#13. Results are released a nnually to inform leaders on potential vulnerabilities to climate change.

The indicators selected by the ND-Gain Program include:

- Vulnerability indic a tors foc used on the following sectors: water, food, health, ecosystem services, human habitat and infrastructure.

- Economic indic ators selected to measure economic freedom as this is generally related to susta inable practices

- Govemment indic a tors that emphasized fair polic ies

- Social indic a tors that mea sured citizen participation and intemational collaboration

Each country receives a value for each indic ator and these values are used to calculate an overall ND-GAIN Score. ${ }^{31}$

\footnotetext{
30 Intemational Institute for Environment and Development (IIED), 2013, Tracking Adaptation and Measuring Development (TAMD) in Ghana, Kenya, Mozambique, Nepal, Pakistan: Meta-analysis Find ings from Appraisal and Design Phase, available from: http://pubs.iied.org/pdfs/G03631.pdf.

31 University of Notre Dame Global Adaptation Index (ND-GAIN), 2013, Detailed Methodology Report, available from: http:// www3.nd.edu/ nchawla/methodology.pdf.
} 


\section{Applicability to Boston}

As the ND-GAIN index is designed to evaluate whole countries, not all of the ind ic ators used in their model are applicable to Boston. Appendix 8 contains a list of all the c limate vulnerability indic ators used in the ND-GAIN index, and below a re specific vulnerability indic ators which ma ye applic able to Boston:

- Coastal infrastructure indic ators that consider what percent of the population lives at or below 5 meters a bove sea level ${ }^{32}$

- Energy infrastruc ture indic ators that mea sure energy struc tures that a re at risk of c limate-related events, and the popula tion with access to reliable electric ity ${ }^{33}$

- Transport infrastructure indic ators that include frequency of flood per unit area and the percentage of surfaces paved ${ }^{34}$

6. The United Nations Office for Disaster Risk Reduction (UNISDR), "Disaster Resilience Scorecard for Cities"

\section{Oveniew}

The Disaster Resilience Scorecard provides a series of assessments that helps cities understand their resilience to na tural disasters. ${ }^{35}$ The scorecard is meant to a llow cities to understand their c urrent level of disa ster resilience, to prioritize investments and funds, and track progress in disaster resilience improvements. ${ }^{36}$ The sc orecard conta ins 85 disa ster resilience criteria, foc used on 1) research, 2) organization, 3) infrastructure, 4) response capability, 5) environment, and 6) recovery. ${ }^{37}$

\section{Applicability to Boston}

As the Disaster Resilience Scorecard is meant to be general and relevant to most cities, the disaster resilience criteria a re likely applic able to Boston. In a dd ition, the organization of criteria into "ten essentials of disaster" management is a lso likely useful.

\section{Climate Change Doc uments Specific to Boston}

We also conducted a literature review of Boston's artic ula ted climate change concems and policy priorities related to clima te change adaptation. This information will help the team select indic ators that measure adaptation progress a ga inst Boston's top clima te change concems and policy priorities. The literature review consisted of:

- Boston's Climate Action Plan (2011),

- Climate Ready Boston (2013),

- DRAFT2014 Climate Action Plan, and

- Other climate change-rela ted materials for Boston.

Note that this doc ument is based solely on a literature review and initial conversations with the City of Boston and TBHA, and may not be comprehensive or completely

\footnotetext{
32 ND-G AIN, 2013, 31-2.

33 Ibid., 32-3.

34 Ibid., 33-4.

35 United Nations O ffice for Disaster Risk Reduc tion (UNISDR), 2014, Disa ster Resilience Scorec ard for Cities, Working Document, prepared by AECOM and IBM, available from:

http://www.unisdr.org/2014/campaign-cities/Resilience\%20Sc oreca rd\%20V1.5.pdf.

${ }^{36} \mathrm{lbid}$.

${ }^{37}$ Ibid., 2.
} 
accurate. Furthermore, this list of climate change concems and policy priorities will likely be modified based on additional conversations with the City and TBHA, working sessions with a technical advisory committee developed for this project, and meetings with a strategic committee developed by the City to assist with updating the Climate Action Plan this year.

\section{A. Top Climate Change Concems for Boston}

Based on conversations with the City of Boston and review of the 2011 Climate Action Plan, below is a list of proposed top climate change concems for Boston:

- Sea level rise/flooding

- Increased frequency and intensity of stoms

- Increased frequency and intensity of heat waves ${ }^{38}$

\section{B. Top Climate Change Adaptation Policy Prionities for Boston}

Boston is undertaking a variety of initiatives to help prepare for and adapt to the climate change concems listed above. Based on a literature review, below is a proposed list of the City's top policy prionities to help Boston prepare for and adapt to climate change:

1. Vulnerability of build ings, water and sewer infrastructure, public transportation, and seawalls to climate change impacts (flooding, stoms, and heat)

a. General munic ipal buildings (facilities id entified as vulnera ble to sea level rise, flooding, and storm surge including City Hall and others) ${ }^{39}$

b. New buildings and build ing renovations (considering climate change during planning, zoning and project review; certa in facilities must adhere to preparedness and resilience guidelines) ${ }^{40}$

c. Schools, community centers, and neighborhood emergency shelters (facilities that act as emergency shelters, but also have high-prionity vulnerabilities) ${ }^{41}$

d. Police, fire and EMS stations (facilities identified as vulnerable to sea level rise, flooding, and storm surge)

e. Public housing and other property (fac ilities identified as high-p rionity vulnerable properties) ${ }^{42}$

2. Vulnerability of Boston's transportation and water infra struc ture system

\footnotetext{
${ }^{38}$ Climate Action Leadership Committee, 2011, Climate Action in Boston: Recommendations of the Boston Climate Action Leadership Committee and the Community Advisory Committee on Climate Action, City of Boston.

39 Spector, C. and L Bamberger, 2013, Climate Ready Boston: Munic ipal Vulnerability to Climate Change. Climate Preparedness Task Force, City of Boston, October, a vailable from: http://www.cityofboston.gov/climate/adaptation/.

40 Climate Action Leadership Committee, 2011, Mayor Martin J. Wa Ish, 2014, Greenovate Boston: 2014 Climate Action Plan Update, C ity of Boston, ava ilable from:

http://www.c ityofboston.gov/climate/bostonsplan/.

${ }^{41}$ Spector and Bamberger, 2013.

42 lbid.
} 
a. Transporta tion (extreme heat and stoms can affect roads, sidewalks, railroad tracks, public transportation; sea level rise and stormscan result in flooding of transport routes)

b. Water and Sewer Infrastructure (effect of sea level rise and increased precipitation on city's storm water and sewer system) ${ }^{43}$

3. Vulnerability of Boston's neighborhoods and environment, which include their build ings a nd homes, historic character, and natural features

a. Historic preservation (historic distric ts built on fill and susceptible to flooding; historic sites susceptible to flooding, sea level rise and erosion) ${ }^{44}$

b. Parks and the urban forest (changes in precipitation and temperature can stress trees and vegetation $)^{45}$

c. Open space and wetlands (protecting wetlands to guard aga inst sea level rise $)^{46}$

4. Public health, safety and heat

a. Excessive heat events affecting vulnerable populations, tourists, etc. ${ }^{47}$

b. Exc essive heat events affecting the electric grid (a ir conditioning using up elec tric ity) 48

c. Potential emergencies that could worsen due to climate change, such as cleaning up conta minated flood water and other debris after floods, directing traffic around flood zones ${ }^{49}$

d. Developing municipal emergency plans that include climate change preparedness, and those plans must be reviewed and practiced

e. Preparing a sufficient vehic le fleet in Boston to cope with emergencies

f. Public safety during emergencies, such as resc uing people trapped in homes, providing access to emergency shelters

g. Helping Boston businesses and residents prepare for emergencies

h. Continuing care for vulnerable individuals duning a major disaster (those with chronic health conditions, etc.) ${ }^{50}$

5. Coordination between State and Federal agencies to address climate change concems [coordination is essential for inc reasing the climate preparedness of Boston]

a. Major infra struc ture not under city jurisdic tion (several systems and infrastruc ture, including MBTA, Logan Airport, Deer Island Waste Water Trea tment Plant, Charles River Dam, etc.

\footnotetext{
$43 \mathrm{lbid}$.

$44 \mathrm{Ibid}$.

${ }^{45}$ Climate Action Leadership Committee, 2011; Spector and Bamberger, 2013.

${ }^{46}$ Climate Action Leadership Committee, 2011.

47 Spector and Bamberger, 2013.

48 Mayor Martin J. Walsh, 2014.

49 Spector and Bamberger, 2013.

50 Spector and Bamberger, 2013.
} 
b. Need for operational coordination emergency response will require more coordination and regional planning with the Commonwealth, neighboring cities, private and institutional entities ${ }^{51}$

6. Community outreach and public engagement

a. Developing educational materials, outreach strategies, and community/orga nizational networks on climate change preparedness to engage public and spread awareness 52

7. Resources/funding to support and research climate change preparedness

a. Office of Administration and Finance recognizes that all departments need to address climate change impacts in theircapital and operating budget proposals ${ }^{53}$

b. Securing funding to support climate change preparedness capital projects ${ }^{54}$

c. Collect and a nalyze new data, and integrate new data into CAP55

$51 \mathrm{lbid}$.

52 Climate Action Leadership Committee, 2011.

53 Spector and Bamberger, 2013.

${ }^{54}$ Climate Action Lea dership Committee.

$55 \mathrm{lbid}$. 


\section{Appendix 2: List of Potential Indic ators to Measure Climate Change Preparedness in Boston, MA.}

\begin{tabular}{|c|c|c|}
\hline $\begin{array}{l}\text { Recommended } \\
\text { Sectors }\end{array}$ & $\begin{array}{c}\text { Key Issues Related to Climate } \\
\text { Change }\end{array}$ & Potential Indicators \& Metrics \\
\hline \multicolumn{3}{|c|}{ 1. Governance \& Government } \\
\hline $\begin{array}{l}\text { Information and } \\
\text { understanding }\end{array}$ & $\begin{array}{l}\text { Information and data are available to } \\
\text { adequately address climate change and } \\
\text { related events } \\
\text { - Studies conducted } \\
\text { (vulnerability, scenarios to assess } \\
\text { sea level rise (SLR), temperature) } \\
\text { - Data availability \& gaps }\end{array}$ & $\begin{array}{l}\text { Studies: } \\
\text { - Knowledge of hazards that the city faces and their likelihood (priority vulnerabilities are identified) }{ }^{1} \\
\text { - } \quad \text { Knowledge of exposure and vulnerability }{ }^{2} \\
\text { - Understanding of critical assets (e.g., infrastructure) and the relationships between them are identified in } \\
\text { the form of potential "failure chains" } 3 \\
\text { - Process ensuring frequent and complete updates of climate change-related scenarios (e.g., buildings, } \\
\text { schools, ecosystem services) } \\
\text { - Percent geographic area of City surveyed to identify vulnerable areas } \\
\text { - } \quad \text { Percentage of applicable City sectors that have been assessed for vulnerability following standardized } \\
\text { procedures } \\
\text { - Number of climate change adaptation studies conducted } \\
\text { - } \quad \text { Provide climate-preparedness examples and pilot innovative solutions using City-owned facilities and land } \\
\text { the community are identified (and ways to increase preparedness) } \\
\text { - Partnership with research universities developed to determine, analyze, test and implement new climate- } \\
\text { preparedness strategies } \\
\text { - Studies conducted to determine new climate resilient technologies (e.g., new pavement materials, green } \\
\text { infrastructure) } \\
\text { Data availability \& gaps: } \\
\text { - Central Preparedness Information System is established containing information on current knowledge and } \\
\text { data gaps } \\
\text { - The Climate Action Plan (CAP) identifies key preparedness planning data and information necessary to meet } \\
\text { goals/objectives }\end{array}$ \\
\hline $\begin{array}{c}\text { Government planning } \\
\text { activity }\end{array}$ & $\begin{array}{l}\text { Government is prepared to adequately } \\
\text { address climate change and related } \\
\text { events } \\
\text { - City planning } \\
\text { o Climate change integrated } \\
\text { into all city planning } \\
\text { o Operates under uncertainty } \\
\text { and is flexible }\end{array}$ & $\begin{array}{l}\text { City planning: } \\
\text { - The degree to which planning, capacity and coordination to effectively prepare for and respond to climate } \\
\text { change and extreme weather events is in place } \\
\text { - Governing structure has established policy definitions for } 1 \text { ) required planning horizons, 2) expected future } \\
\text { conditions, and 3) "acceptable risk" from coastal flooding, extreme precipitation and heat } \\
\text { - Number/percentage of City plans with effective climate change preparedness integrated (e.g., emergency } \\
\text { response) }\end{array}$ \\
\hline
\end{tabular}




\begin{tabular}{|c|c|c|}
\hline & $\begin{array}{l}\text { - Plans are adaptive and reflect } \\
\text { new data/emerging issues } \\
\text { - Data use in decisions } \\
\text { - Monitoring progress }\end{array}$ & $\begin{array}{l}\text { - Climate preparedness is a key component of all City planning; integrated into zoning, all project and permit } \\
\text { review and licensing/regulations and guidelines that govern these processes } \\
\text { - } \quad \text { Climate change is mainstreamed into city plans and programs }{ }^{5} \\
\text { - } \quad \text { Establish guidelines on climate-preparedness planning horizons } \\
\text { - } \quad \text { Coordination of all relevant pre-event planning and preparation activities exists for the city's area, with } \\
\text { clarity of roles and accountability across all relevant organizations }{ }^{7} \\
\text { - } \quad \text { Extent to which any proposals in government is also evaluated for climate change resilience benefits or } \\
\text { impairments }{ }^{8} \text { ) } \\
\text { - City adaptation and preparedness plans are linked to climate data (e.g., SLR, heat, and storm } \\
\text { frequency/intensity projections) \& vulnerability assessment surveys } \\
\text { - Climate preparedness analysis is part of every capital decision (Office of Administration and Finance can } \\
\text { modify its process to institutionalize this) } \\
\text { - Plans are adaptive and flexible; preparedness plans and associated regulations and incentives are indexed } \\
\text { to monitored environmental conditions (e.g., sea level, storm intensity), with updates linked to actual } \\
\text { monitored/observed conditions } \\
\text { Data use in decisions: } \\
\text { - Extent to which climate information is i) used to inform responses to climate change and ii) generated at all } \\
\text { levels of society }{ }^{9} \text { The degree to which information and data are available and used to adequately address climate } \\
\text { change and related events } \\
\text { - } \quad \text { Extent to which climate information is used to inform responses to climate change (data readily accessible, } \\
\text { data are used to inform adaptation interventions) } \\
\text { Monitoring progress: } \\
\text { - Indicators are established to monitor progress and report annually }\end{array}$ \\
\hline Coordination & $\begin{array}{l}\text { Boston is coordinating its climate change } \\
\text { plans and responses with other partners } \\
\text { to its best ability } \\
\text { Coordination with state, regional } \\
\text { and federal partners (e.g., Logan, } \\
\text { Massachusetts Bay Transportation } \\
\text { Authority (MBTA), emergency } \\
\text { response) }\end{array}$ & $\begin{array}{l}\text { Coordination with state, regional and federal partners } \\
\text { - Interoperability with neighboring cities/states and other levels of government of critical systems and } \\
\text { procedures } 10 \\
\text { - } \quad \text { Extent and quality of coordination of climate risk management across relevant institutions }{ }^{11} \\
\text { - Government structure is in place to coordinate inter- and intra-governmental climate preparedness } \\
\text { activities across Metro Boston area and outside of Boston } \\
\text { - Coordination of all relevant event response activities, with clarity of roles and accountability across all } \\
\text { relevant organizations; participation and coordination of all relevant organizations in the structure(s) defined }{ }^{12} \\
\text { - Based on \# of state and federal preparedness activities, percentage of relevant City departments that have } \\
\text { been active in either informing their operations with state/federal/regional efforts } \\
\text { - } \quad \text { Plans for non-municipal infrastructure includes relevant sections for City activities and City Plans (and vice } \\
\text { versa) } \\
\text { - The City's emergency response is coordinated with neighboring cities and private institutions } \\
\text { - } \quad \text { Mechanism/plan for coordination developed and implemented for regional preparedness planning, } \\
\text { development of regulatory requirements, infrastructure investment and other programs/policies (e.g., } \\
\text { preparedness of vital infrastructure that City has no jurisdiction) }\end{array}$ \\
\hline
\end{tabular}




\begin{tabular}{|c|c|c|}
\hline $\begin{array}{l}\text { Government continuity } \\
\text { (IT, critical } \\
\text { infrastructure, buildings) }\end{array}$ & $\begin{array}{l}\text { Government is able to continue } \\
\text { operating and providing critical services } \\
\text { during climate related events } \\
\text { - Vulnerability of government } \\
\text { buildings and critical services \& } \\
\text { adaptation measures (e.g., City Hall, } \\
\text { first floor, core digital and } \\
\text { communications infrastructure on } \\
\text { first floor) } \\
\text { Government personnel }\end{array}$ & $\begin{array}{l}\text { Vulnerability of government buildings and critical services } \& \text { adaptation measures } \\
\text { - } \quad \text { High-priority facility specific vulnerabilities reduced (e.g., those identified in } 2013 \text { assessment - City Hall; } \\
\text { report on progress annually) } \\
\text { - } \quad \text { Percent of government buildings and critical services considered vulnerable to climate-related events } \\
\text { - } \quad \text { New City buildings and repair of existing buildings include climate preparedness measures (e.g., elevating } \\
\text { sensitive equipment, flood proofing) } \\
\text { - } \quad \text { Percentage of City's critical services (IT, communications, and transportation centers) able to function in } \\
\text { emergency situations } \\
\text { - Identified measures for climate-change resiliency of government buildings and critical services are being } \\
\text { implemented } \\
\text { - Protection of critical law and order/responder assets (e.g., emergency vehicles, critical IT system, key } \\
\text { buildings) } \\
\text { - } \quad \text { Disaster resilience of prison system }{ }^{14} \\
\text { - } \quad \text { Assurance of continuity of all critical administration functions }{ }^{15} \\
\text { - } \quad \text { Assurance of continuity of computer systems and data critical to government continuity and other critical } \\
\text { infrastructure }{ }^{16} \\
\text { - } \quad \text { Number or percentage municipal buildings with backup generators or alternative energy source } \\
\text { - } \quad \text { The competent committees (e.g., district office, local authorities, private and civic sector) in flood-prone } \\
\text { watersheds have a realistic, effective plan of action at their disposal as part of the flood prevention strategy } \\
\text { Government personnel } \\
\text { - System/plan in place to ensure city workers can reach offices during emergency situation }\end{array}$ \\
\hline Resources/Funding & $\begin{array}{l}\text { Finances and resources are available to } \\
\text { adequately address climate change and } \\
\text { related events } \\
\text { - Finances - existing and potential } \\
\text { - Funds spent } \\
\text { - Staff }\end{array}$ & $\begin{array}{l}\text { Finances - existing and potential } \\
\text { - } \quad \text { Finances and resources are available to adequately address climate change and related events } \\
\text { - } \quad \text { Amount of funds available for climate risk assessments and adaptation projects } \\
\text { - } \quad \text { Adequacy of financial planning for all actions necessary for climate change resilience }{ }^{17} \\
\text { - } \quad \text { Federal dollars secured for climate-informed coastal restoration projects }{ }^{18} \\
\text { - } \quad \text { Dollars secured by the City to support climate change preparedness/adaptation } \\
\text { - } \quad \text { Number of grants submitted to support climate change preparedness measures/\# grants won } \\
\text { - } \quad \text { Capital funding for projects to collect data on climate change and resilience measures } \\
\text { - } \quad \text { Operating funding to meet all operating costs of climate change resilience activities } \\
\text { - } \quad \text { Contingency funds for post climate change event/disaster recovery (“Rainy-day funding”; most severe } \\
\text { event) } \\
\text { - } \quad \text { Financial support for climate change mainstreaming and related initiatives }{ }^{19} \\
\text { - } \quad \text { Required funding for CCA provided } \\
\text { - } \quad \text { Capital and budget proposals incorporate climate change impacts } \\
\text { - } \quad \text { Resources acquired to develop green infrastructure } \\
\text { - } \quad \text { Funding secured for flood protection projects } \\
\text { Funds spent } \\
\text { - } \quad \text { Amount of money spent by government to repair sites in Boston because of climate-related damage }\end{array}$ \\
\hline
\end{tabular}




\begin{tabular}{|c|c|c|}
\hline & & $\begin{array}{l}\text { Staff } \\
\text { - Number of disaster experts on staff in city government or number of people who have resilience as part of } \\
\text { their job description } \\
\text { - Availability of skills and experience in climate change and disaster resilience (e.g., risk identification, } \\
\text { mitigation, planning, response and post-event response) } \\
\text { - } \quad \text { Director or other official with climate action responsibility hired } \\
\text { - } \quad \text { Required staff for CCA provided }\end{array}$ \\
\hline \multicolumn{3}{|c|}{ 2. Business \& Institutions } \\
\hline Commercial buildings & $\begin{array}{l}\text { Commercial buildings are adequately } \\
\text { prepared to withstand climate change } \\
\text { and related events } \\
\qquad \text { Vulnerability of commercial } \\
\text { buildings \& adaptation measures }\end{array}$ & $\begin{array}{l}\text { Vulnerability of commercial buildings } \& \text { adaptation measures } \\
\text { - Number of/percent of commercial buildings considered vulnerable to climate-related events } \\
\text { - } \quad \text { New commercial buildings and repair of existing commercial buildings include climate preparedness } \\
\text { measures (e.g., withstand sea level rise, not constructed in high-risk flood zones) } \\
\text { - Identified measures for climate-change resiliency of commercial buildings are being implemented } \\
\text { - } \quad \text { Existence of building codes to address climate-related risks/application of codes }{ }^{21} \\
\text { Percent of capital improvement projects which incorporate hazard mitigation and climate change principles } \\
\text { - Percentage of Boston's buildings/critical infrastructure adapted for climate change resiliency or } \\
\text { implementing climate adaptation measures }\end{array}$ \\
\hline Business continuity & $\begin{array}{l}\text { Businesses are prepared to continue } \\
\text { operating during climate change related } \\
\text { events } \\
\text { - Vulnerable business buildings } \\
\text { and adaptation measures } \\
\text { - Business continuity }\end{array}$ & $\begin{array}{l}\text { Vulnerable business buildings } \& \text { adaptation measures } \\
\text { - } \quad \text { Number of/percent of business buildings considered vulnerable to climate-related events } \\
\text { - } \quad \text { Identified measures for climate-change resiliency of business buildings are being implemented } \\
\text { Business continuity } \\
\text { - } \quad \% \text { employment at risk } \\
\text { - } \% \text { of business output at risk } \\
\text { - } \quad \text { Programs are established to assist small businesses in increasing preparedness and developing business } \\
\text { continuity plans } \\
\text { - } \quad \text { Workers are protected in extreme weather } \\
\text { - } \quad \text { Number of/Percentage of vulnerable businesses with continuity of business plan [prepared and } \\
\text { implemented plans]; business plan to recover from emergency } \\
\text { - } \quad \text { Boston residents are able to get to work during climate-related events } \\
\text { - } \quad \text { Space available within the City for workers when office space is not accessible } \\
\text { - } \quad \text { Percentage of lost productivity due to climate-related flooding } \\
\text { - } \\
\text { Number of lost work days because of climate-related events } 22\end{array}$ \\
\hline
\end{tabular}




\begin{tabular}{|c|c|c|}
\hline \multicolumn{3}{|c|}{ 3. Social \& Natural Capital } \\
\hline $\begin{array}{l}\text { Parks, open space and } \\
\text { green infrastructure }\end{array}$ & $\begin{array}{l}\text { Parks, trees and open space are prepared } \\
\text { to withstand climate change and related } \\
\text { events; parks, trees, and green } \\
\text { infrastructure are prioritized to help } \\
\text { reduce the urban heat island effect } \\
\text { - Vulnerability of parks and open } \\
\text { space \& adaptation measures } \\
\text { - Open space preservation } \\
\text { - Tree canopy } \\
\text { o Acquire funds } \\
\text { o Trees remain healthy (health } \\
\text { o } \text { monitored) } \\
\text { Greentinue Grow Boston } \\
\end{array}$ & $\begin{array}{l}\text { Vulnerability of parks and open space } \& \text { adaptation measures } \\
\text { - } \quad \text { Percent of parks and open space areas considered vulnerable to climate change and related events } \\
\text { - } \quad \text { Identified adaptation measures are implemented in Boston Harbor Islands and other parks/open space } \\
\text { Open space preservation } \\
\text { - } \quad \text { Amount and type of land cover preserved as open space } \\
\text { - } \quad \text { Square miles of green space or vegetative cover } \\
\text { - } \quad \text { Area or capacity of urban agriculture including community gardens } \\
\text { - } \quad \text { City's new open space plan incorporates climate change } \\
\text { Tree canopy } \\
\text { - } \quad \text { Plan to significantly increase tree canopy cover is developed and implemented } \\
\text { - } \quad \text { Growth of total tree inventory } \\
\text { - } \quad \text { Health of trees in Boston is monitored and maintained } \\
\text { - } \quad \text { Percentage of Boston that has a tree canopy } \\
\text { - } \quad \text { Grow Boston Greener's tree initiative is prioritized as an important initiative } \\
\text { Green infrastructure } \\
\text { - } \quad \text { Percentage or number of building with cool or green roofs } \\
\text { - } \quad \text { Legislative and regulatory means of expanding requirements for green infrastructure and coastal } \\
\text { protection are explored }\end{array}$ \\
\hline Ecosystem Components & $\begin{array}{l}\text { Ecosystem is able to withstand impacts } \\
\text { of climate change and related } \\
\text { events/ecosystem components can be } \\
\text { utilized to decrease vulnerability of a } \\
\text { system } \\
\text { - Vulnerability of ecosystem to } \\
\text { climate change and related events } \\
\text { - Ecosystem protects system } \\
\text { from impacts of climate change }\end{array}$ & $\begin{array}{l}\text { Vulnerability of Boston's ecosystem to climate change and related events } \& \text { adaptation measures } \\
\text { - The degree to which natural ecosystems in Greater Boston are able to withstand impacts of climate change } \\
\text { and related events/ecosystem components and can be utilized to decrease vulnerability of a system. } \\
\text { - } \quad \text { Ecosystem components are specifically identified and managed as critical assets to disaster resilience } \\
\text { - } \quad \text { Awareness of the role that ecosystem services may play in the city's climate change resilience (UNISDR) } \\
\text { - } \quad \text { Ecosystem health (change in health of services in last five years) }{ }^{23} \\
\text { water protection - amount and type of land cover preserved as open space, regulation changes, targeted public } \\
\text { funding, enhanced monitoring, invasive species removal) } \\
\text { - } \quad \text { Invasive species are removed or controlled } \\
\text { - } \quad \text { Percentage of identified critical natural resources that have been evaluated } \\
\text { - } \quad \text { Biodiversity and landscape diversity is promoted } \\
\text { - } \quad \text { Healthy watersheds and natural corridors are protected } \\
\text { Ecosystem protects system from impacts of climate change } \\
\text { - } \quad \text { Beach sand nourishment efforts are implemented }{ }^{24} \\
\text { - } \quad \text { Local wetlands ordinance is implemented that takes sea level rise into account } \\
\text { Shore protection techniques and open space preserves allow beaches and coastal wetlands to gradually } \\
\text { move inland as sea level rises }\end{array}$ \\
\hline
\end{tabular}




\begin{tabular}{|c|c|c|}
\hline $\begin{array}{c}\text { Cultural Resources } \\
\text { (heritage, preservation) }\end{array}$ & $\begin{array}{l}\text { Historical sites and districts are prepared } \\
\text { to withstand climate change and related } \\
\text { events } \\
\text { - Vulnerability of historical } \\
\text { sites/districts \& adaptation } \\
\text { measures (e.g., Back Bay } \\
\text { Architectural District, Bay } \\
\text { Village Historic District) }\end{array}$ & $\begin{array}{l}\text { Vulnerability of historical sites/districts \& adaptation measures } \\
\text { - } \quad \text { Percentage of/Number of historical buildings/sites susceptible to sea level rise/flooding/erosion } \\
\text { - } \quad \text { Number of historical buildings/sites updated with climate resilience measures } \\
\text { Identified measures for climate-change resiliency of historical buildings/sites are being implemented }\end{array}$ \\
\hline \multicolumn{3}{|c|}{ 4. Residential Neighborhoods } \\
\hline Residences/buildings & $\begin{array}{l}\text { Residences and buildings are prepared to } \\
\text { withstand climate change and related } \\
\text { events } \\
\text { - Vulnerability of residential } \\
\text { buildings/areas \& adaptation } \\
\text { measures }\end{array}$ & 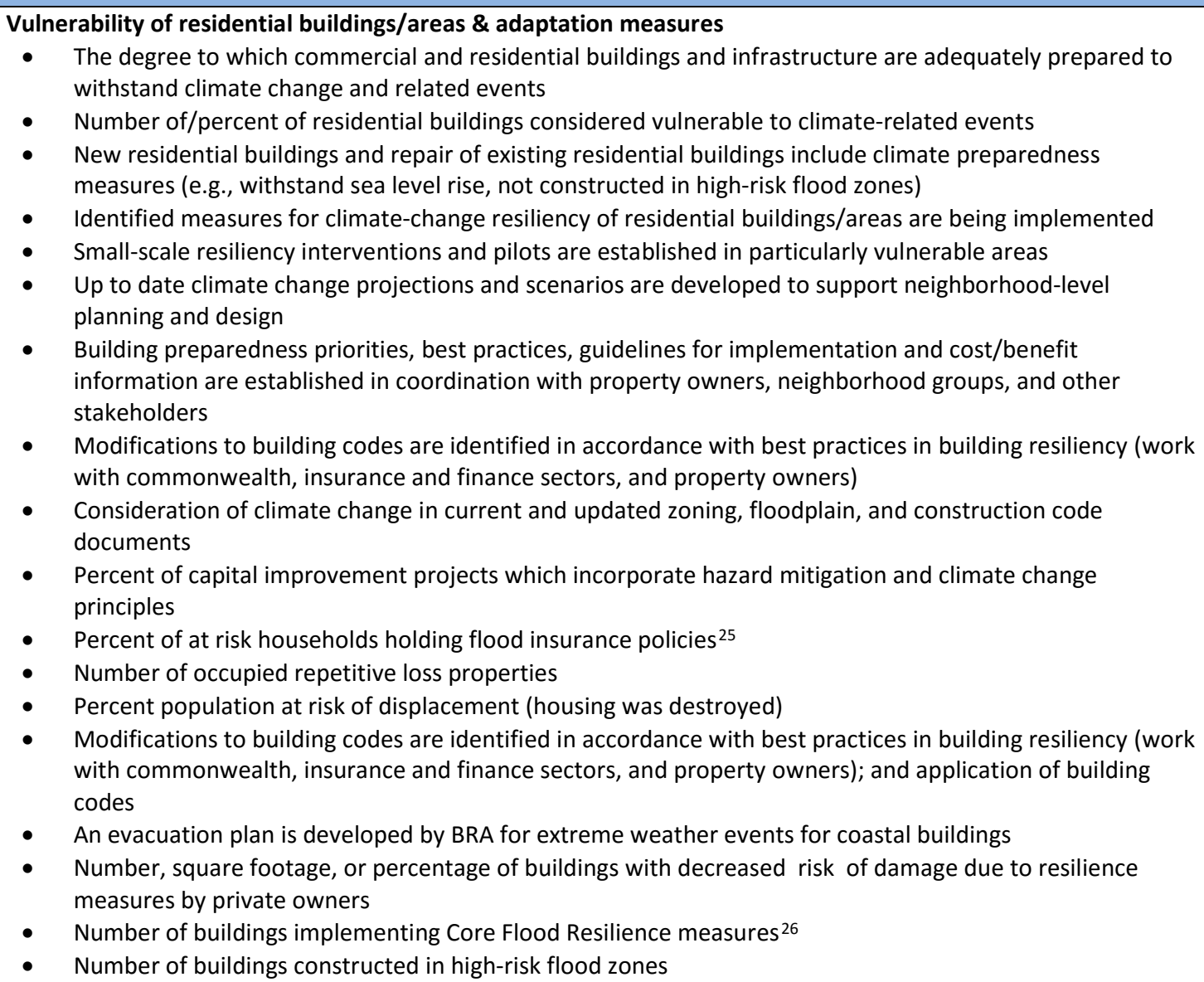 \\
\hline
\end{tabular}




\begin{tabular}{|c|c|c|}
\hline & & $\begin{array}{l}\text { - Capital construction plans for public housing address impacts of climate change and current vulnerable } \\
\text { housing units are upgraded/replaced }\end{array}$ \\
\hline \multicolumn{3}{|l|}{ 5. Public Health \& Safety } \\
\hline Public health \& cooling & $\begin{array}{l}\text { Boston residents are not vulnerable to } \\
\text { climate-related health risks \& have } \\
\text { access to needed amenities } \\
\text { - Climate-related deaths } \\
\text { (heat)/illnesses/disease } \\
\text { o Cooling center system } \\
\text { improved } \\
\text { o Air conditioning in houses } \\
\text { o Vulnerable populations stay } \\
\text { o cool } \\
\text { o Worker safety (staff fatigue) } \\
\text { - Vulnerable populations } \\
0 \quad \text { Public housing facilities } \\
0 \quad \text { Access to critical services } \\
\text { (health centers) }\end{array}$ & 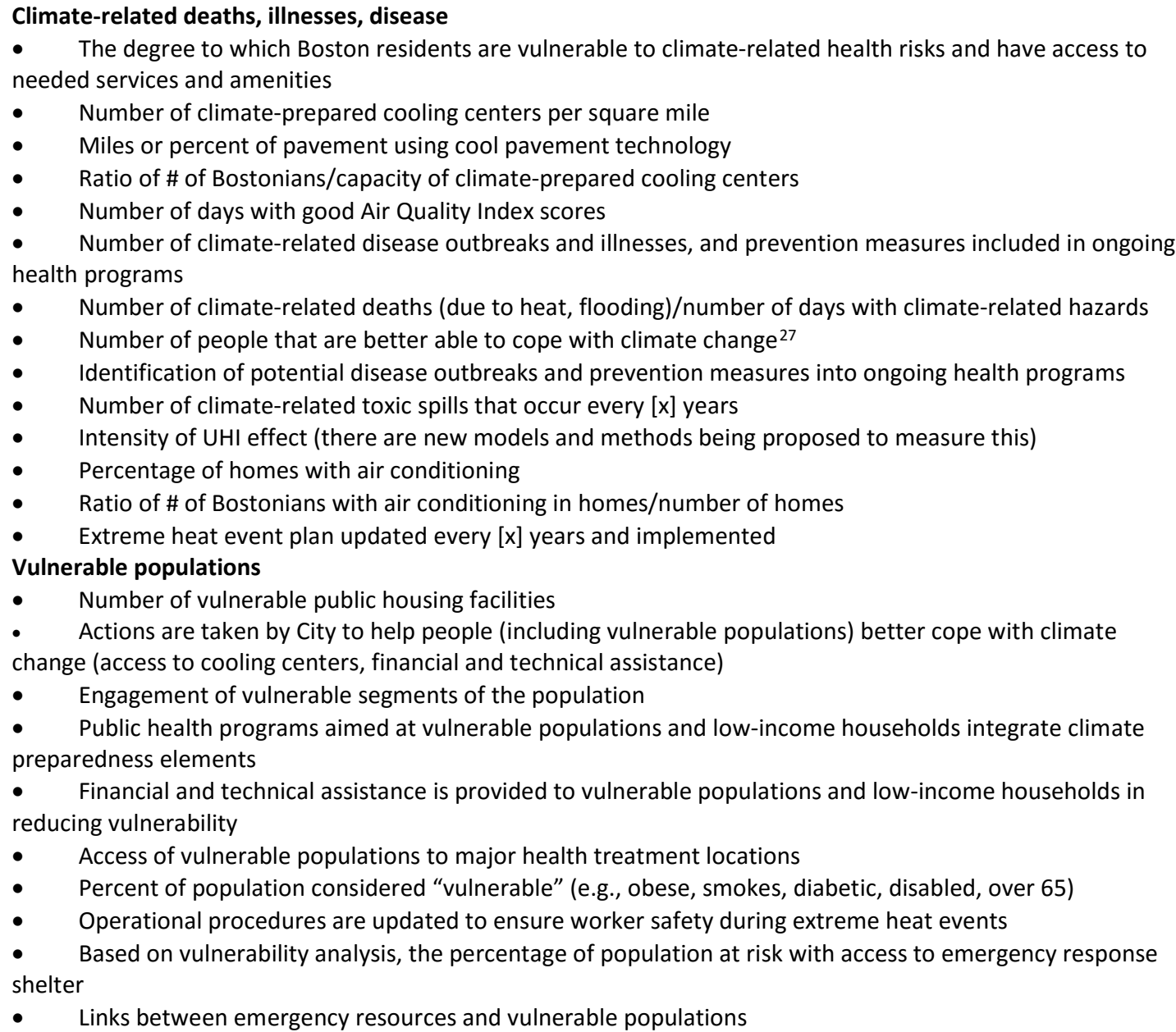 \\
\hline
\end{tabular}




\begin{tabular}{|c|c|c|}
\hline Emergency response & 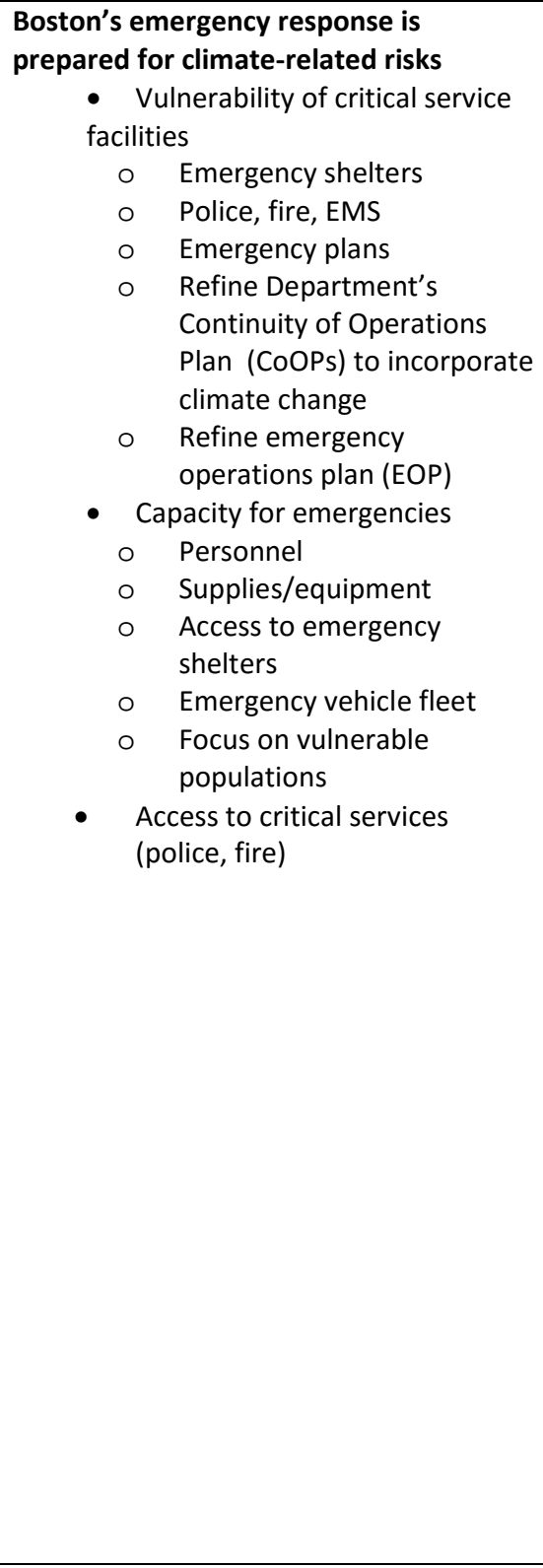 & 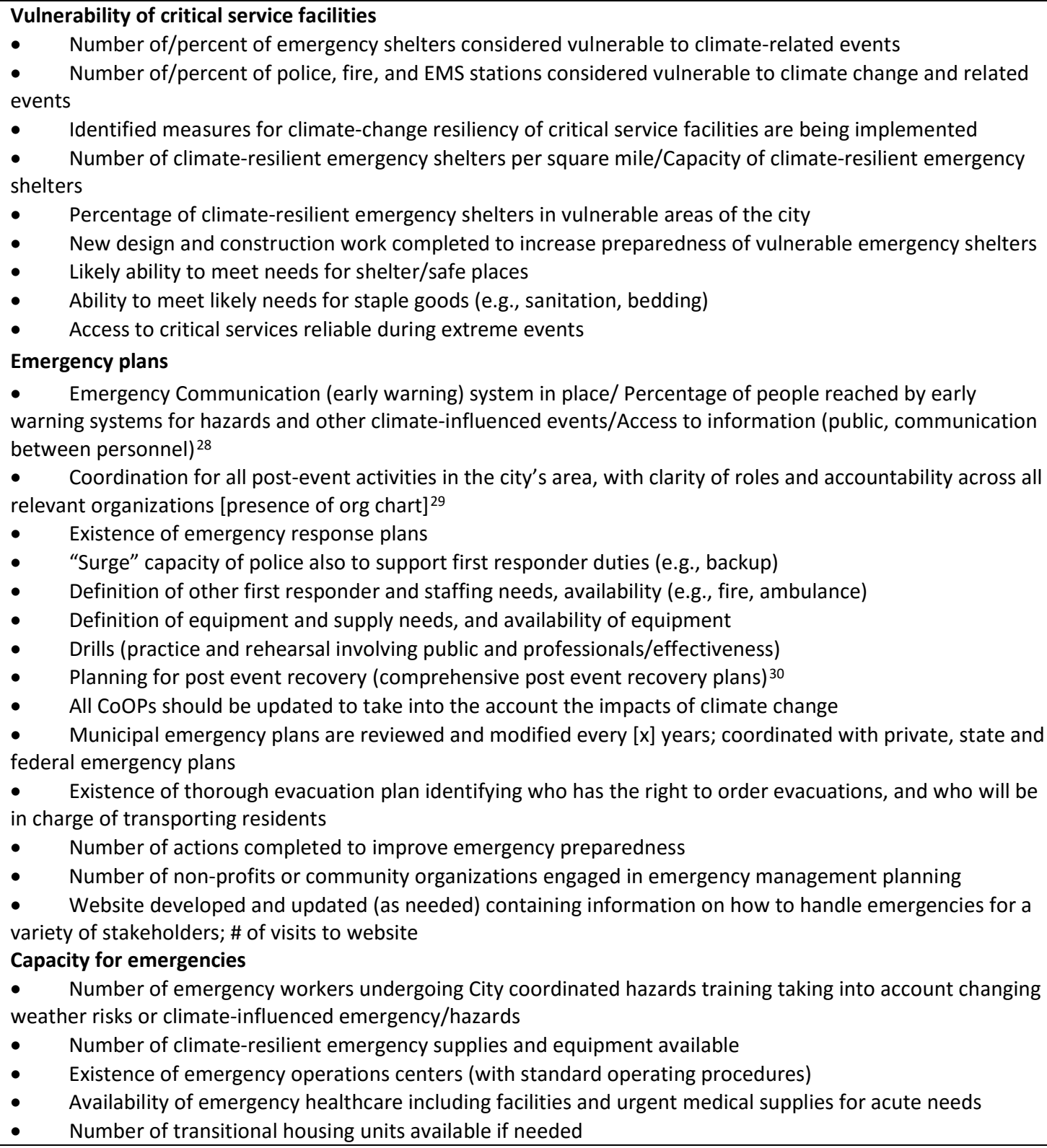 \\
\hline
\end{tabular}




\begin{tabular}{|c|c|c|}
\hline & & $\begin{array}{l}\text { - } \quad \text { Number of police and fire stations } \\
\text { - } \quad \text { Number of emergency shelters } \\
\text { - } \quad \text { Number of emergency vehicles in City } \\
\text { Capacity for cleaning up hazardous spills, contaminated floodwater and debris }\end{array}$ \\
\hline $\begin{array}{l}\text { Health institutions (e.g., } \\
\text { hospitals) }\end{array}$ & $\begin{array}{l}\text { Health institutions are prepared for } \\
\text { climate change and related risks } \\
\qquad \begin{array}{l}\text { Vulnerability of health } \\
\text { institutions \& adaptation } \\
\text { measures }\end{array}\end{array}$ & $\begin{array}{l}\text { Vulnerability of health institutions \& adaptation measures } \\
\text { - } \quad \text { Number of/percent of health institutions considered vulnerable to climate-related events } \\
\text { - } \quad \text { Identified measures for climate-change resiliency of health institutions are being implemented } \\
\text { - } \quad \text { Structural safety and disaster resilience of health care and emergency facilities } \\
\text { - } \quad \text { Percentage of hospital and healthcare facilities implementing climate preparedness into building design } \\
\text { including back-up power } \\
\text { - } \quad \text { Percent of hospitals in } 500 \text {-year floodplain meeting resilience standards } 31 \\
\text { - } \quad \text { Percentage of hospitals with shelter in place and evacuation plans that meet required standards } \\
\text { - } \quad \text { Percent of nursing homes and adult care facilities in } 100 \text {-year floodplain meeting resiliency requirements }\end{array}$ \\
\hline Education facilities & $\begin{array}{l}\text { Education facilities are prepared for } \\
\text { climate change and related risks } \\
\text { f Vulnerability of education } \\
\text { facilities \& adaptation measures }\end{array}$ & $\begin{array}{l}\text { Vulnerability of education facilities \& adaptation measures } \\
\text { - } \quad \text { Structural safety of education facilities (education facilities at risk of damage) }{ }^{33} \\
\text { Loss of teaching time (e.g., number of teaching days lost) }\end{array}$ \\
\hline \multicolumn{3}{|c|}{ 6. Transportation Infrastructure } \\
\hline $\begin{array}{l}\text { Public transportation } \\
\text { (roads, tunnels, airports, } \\
\text { rail - MBTA, highways, } \\
\text { ports) }\end{array}$ & $\begin{array}{l}\text { Public transportation is prepared for } \\
\text { climate change and related risks } \\
\text { - Vulnerability of public } \\
\text { transportation (Roads, tunnels, } \\
\text { airports, rail, MBTA, bridges, ports) } \\
\text { - Public transportation plans }\end{array}$ & $\begin{array}{l}\text { Vulnerability of public transportation } \\
\text { - } \quad \text { Road - service from road system at risk of loss (e.g., miles become impassable) }{ }^{35} \\
\text { - } \quad \text { The degree to which public buildings and infrastructure are adequately prepared to withstand climate } \\
\text { change and related events. } \\
\text { - } \quad \text { Road - survival of critical access and evacuation routes (e.g., emergency routes that become impassable) }{ }^{36} \\
\text { - } \quad \text { Rail/metro - service from rail system at risk of loss (e.g., carrying capacity of affected rail lines) }{ }^{37} \\
\text { - } \quad \text { Airport loss factor (e.g., number of flights out per day after disaster) } \\
\text { - } \quad \text { River/seaport loss factor (e.g., estimated number of dockings per day possible after disaster) }{ }^{39} \\
\text { - } \quad \text { Percentage of projects within flood-prone areas using climate-informed storm water management } \\
\text { technologies } \\
\text { - } \quad \text { Access/transportation to critical infrastructure and services reliable during extreme events } \\
\text { - } \quad \text { Number of/percent of public transportation infrastructure considered vulnerable to climate change and } \\
\text { related events } \\
\text { - } \quad \text { Adaptation measures are being implemented to reduce vulnerability of identified "at-risk" transportation } \\
\text { structures (e.g., new pavement that can withstand extreme weather, elevating high-risk flood zone public } \\
\text { transportation stops) } \\
\text { - } \quad \text { Identified measures for climate-change resiliency of public transportation are being implemented } \\
\text { - } \quad \text { Number of transportation disruptions due to flooding or infrastructure damage } \\
\text { - } \quad \text { Number of or percentage of transportation assets adapted for climate change resilience (e.g., using new } \\
\text { pavement technologies, green infrastructure to control runoff) } \\
\text { - } \quad \text { Number of roads that cross tidal flood zones }\end{array}$ \\
\hline
\end{tabular}




\begin{tabular}{|c|c|c|}
\hline & & $\begin{array}{l}\text { - } \\
\text { - Number of maintenance projects addressing vulnerability of tunnels to seismic activity } \\
\text { - } \quad \text { Number of transportation routes that are vulnerable to flooding } \\
\text { - } \quad \text { Percent of transportation assets adapted for climate change resiliency } \\
\text { Public transportation plans } \\
\text { - Boston Transportation Department incorporates climate change concerns into all planning } \\
\text { Boston Transportation Department coordinates with other transportation authorities }\end{array}$ \\
\hline \multicolumn{3}{|c|}{ 7. Food, Water, Sewer, \& Protective Infrastructure } \\
\hline Food availability & $\begin{array}{l}\text { Boston residents have access to food } \\
\text { during climate-related events } \\
\text { - Food plans } \\
\text { - Food capacity }\end{array}$ & $\begin{array}{l}\text { Food plans } \\
\text { - Development of a comprehensive food security plan for use during emergency events } \\
\text { - Urban agriculture is expanded and resilience of our regional food system is studied } \\
\text { Food capacity } \\
\text { - } \quad \text { Likely ability to continue to feed population (e.g., in event of emergency) } \\
\text { - } \quad \text { Number of grocery stores and food distribution centers with backup power supplies, including generators } \\
\text { or quick connect for generators } 43 \\
\text { - Number of grocery stores or food markets per square mile, with special attention to low-income } \\
\text { neighborhoods }\end{array}$ \\
\hline Water availability & $\begin{array}{l}\text { Good quality water delivery is } \\
\text { unimpeded to Boston residents during } \\
\text { climate-related events } \\
\text { - Water availability throughout } \\
\text { the year and during extreme events }\end{array}$ & $\begin{array}{l}\text { Water availability } \\
\text { - } \quad \text { Size of reservoir stock } \\
\text { - } \quad \text { Water customer service days at risk of loss }{ }^{44} \\
\text { - } \quad \text { Designated critical asset service days (e.g., hospitals) at risk of loss from water failure } \\
\text { - } \quad \text { Water quality } \\
\text { - } \quad \text { Water delivery unimpeded throughout year and during extreme events } \\
\text { - } \quad \text { Combined Sewer Overflows (CSOs) decoupled } \\
\text { - } \quad \text { Capacity for cleaning up contaminated water supply from CSO events and salinization }\end{array}$ \\
\hline $\begin{array}{l}\text { Stormwater and sewer } \\
\text { infrastructure }\end{array}$ & $\begin{array}{l}\text { Stormwater and sewer infrastructure are } \\
\text { prepared for climate change and related } \\
\text { risks } \\
\text { - } \quad \text { Vulnerability of stormwater and } \\
\text { sewer infrastructure \& } \\
\text { adaptation measures } \\
\text { - Stormwater and sewer } \\
\text { infrastructure plans }\end{array}$ & $\begin{array}{l}\text { Vulnerability of stormwater and sewer infrastructure } \& \text { adaptation measures } \\
\text { - } \quad \text { Sanitation customer service days at risk of loss } 45 \\
\text { - } \quad \text { Designated critical asset service days (e.g., hospitals) at risk of loss from sanitation failure } \\
\text { - } \quad \text { Community-wide stormwater fee is instituted } \\
\text { - } \quad \text { Pavement-to-parks/water absorption plan for neighborhoods is created and implemented } \\
\text { - } \quad \text { Cost of restoration } \\
\text { structures (e.g., elevation of Deer Island) } \\
\text { - } \quad \text { Number of/Percentage of water/sewer infrastructure identified as vulnerable to climate change events } \\
\text { - } \quad \text { Identified measures for climate-change resiliency of health institutions are being implemented } \\
\text { - } \\
\text { - }\end{array}$ \\
\hline
\end{tabular}




\begin{tabular}{|c|c|c|}
\hline & & $\begin{array}{l}\text { - } \quad \text { Number of or volume of combined sewer overflows } \\
\text { - } \quad \text { Percentage of pumping stations hardened for increased flood risk } \\
\text { - } \quad \text { Percentage of wastewater treatment facilities linked to backup power generation } \\
\text { - } \quad \text { Percentage of Boston water/sewer infrastructure assets adapted for climate change resiliency } \\
\text { - Number of waste water facilities assets protected or raised above the } 100 \text {-year floodplain }{ }^{46} \\
\text { Stormwater and sewer infrastructure plans } \\
\text { - } \quad \text { Capital asset plan for city's stormwater and sewer system considers climate change } \\
\text { - Policy measures developed (and implemented) to reduce vulnerability of water/sewer infrastructure }\end{array}$ \\
\hline $\begin{array}{c}\text { Protective } \\
\text { infrastructure }\end{array}$ & $\begin{array}{l}\text { Protective infrastructure safeguard } \\
\text { against climate change and related } \\
\text { events } \\
\text { - Protective infrastructure } \\
\text { - Maintenance }\end{array}$ & $\begin{array}{l}\text { Safeguard against climate change and related events } \\
\text { - } \quad \text { Adequacy of protective infrastructure (e.g., ecosystem services providing protection, levees, flood } \\
\text { barriers, sea walls) }{ }^{47} \\
\text { - Number of riparian or natural buffers in capital projects and development } \\
\text { - } \quad \text { Measures implemented to reduce flood risk for coastal infrastructure (e.g., sand bags, stockpiling barriers) } \\
\text { Estimated dollars saved through flood protections projects } \\
\text { Maintenance } \\
\text { - } \quad \text { Effectiveness of maintenance (process exists to maintain protective infrastructure) } \\
48\end{array}$ \\
\hline \multicolumn{3}{|c|}{ 8. Telecommunications } \\
\hline Telecommunications & $\begin{array}{l}\text { Telecommunications system is prepared } \\
\text { for climate change and related events } \\
\text { - Vulnerability of } \\
\text { telecommunications \& adaptation } \\
\text { measures } \\
\text { - Telecommunications plans }\end{array}$ & $\begin{array}{l}\text { Vulnerability of telecommunications } \& \text { adaptation measures } \\
\text { - } \quad \text { Number of climate-resilient temporary charging stations per square mile } \\
\text { - } \quad \text { Number of critical telecommunications facilities implementing climate resilience measures } \\
\text { - } \quad \text { Designunications service days at risk of loss } 49 \\
\text { water and energy systems, traffic control) } \\
\text { - } \quad \text { Cost of restoration of communications services } \\
\text { - } \quad \text { Identified measures for climate-change resiliency of telecommunications systems are being implemented } \\
\text { - Number of/percentage of critical telecommunications facilities/systems identified as vulnerable to climate } \\
\text { change and related events } \\
\text { - Percentage of Boston's telecommunication system transitioned to fiber optics or other more resilient } \\
\text { cables } \\
\text { Telecommunications plans } \\
\text { - } \quad \text { Percentage of telecommunication providers with business continuity plans for Boston }\end{array}$ \\
\hline
\end{tabular}




\begin{tabular}{|c|c|c|}
\hline \multicolumn{3}{|c|}{ 9. Electricity \& Fuel } \\
\hline Electric grid & $\begin{array}{l}\text { Electricity is unimpeded to Boston } \\
\text { because of climate change or related } \\
\text { events } \\
\text { - Vulnerability of electric grid \& } \\
\text { adaptation measures } \\
\text { - Electric grid plans }\end{array}$ & 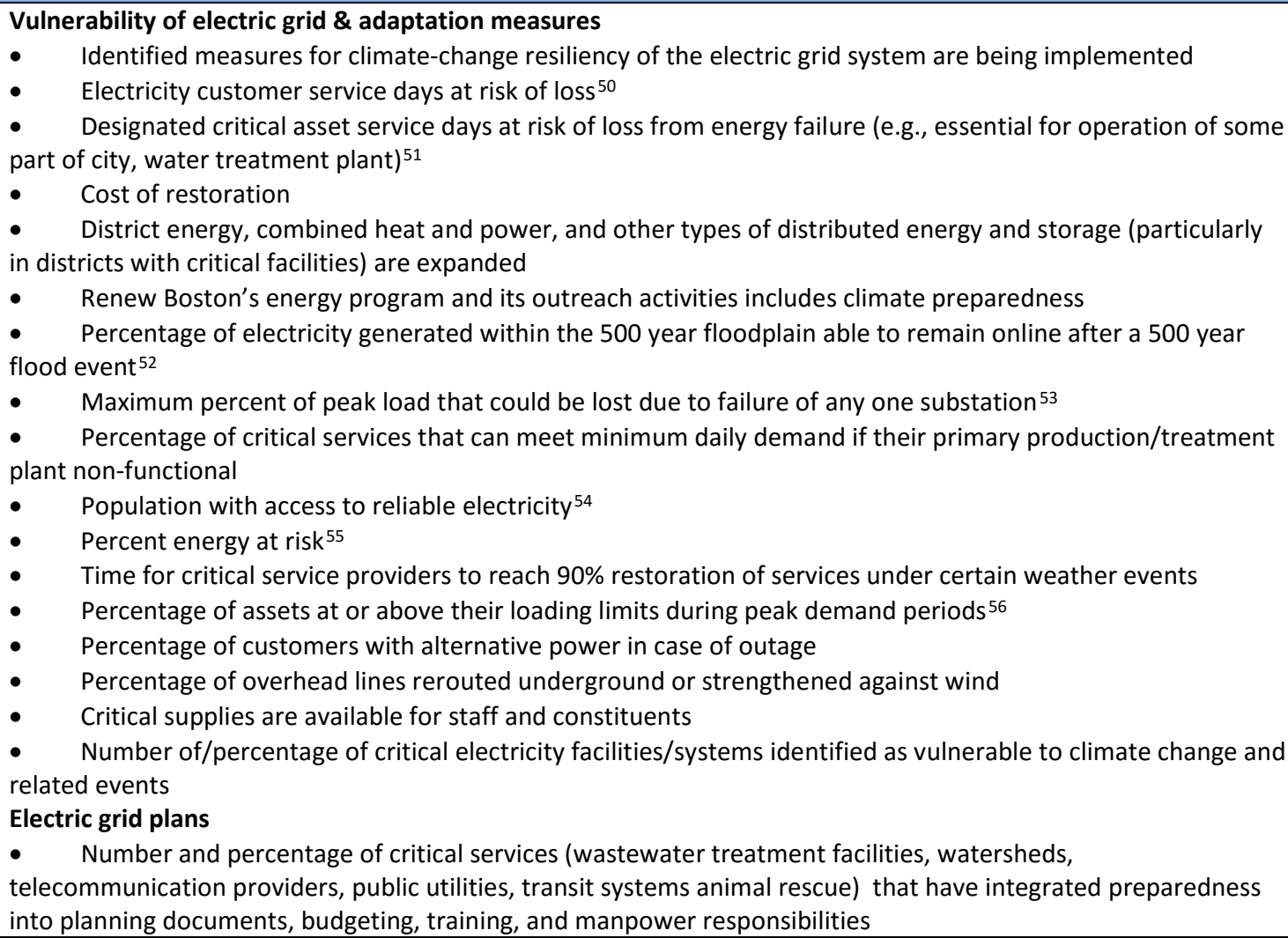 \\
\hline Fuel & $\begin{array}{l}\text { Fuel availability is unimpeded because of } \\
\text { climate change or related events } \\
\text { - Vulnerability of gas pipes \& } \\
\text { adaptation measures } \\
\text { - Fuel plans }\end{array}$ & $\begin{array}{ll}\text { - } & \text { Vulnerability of gas pipes and adaptation measures } \\
\text { - } & \text { Safety and integrity of gas system }{ }^{57} \\
\text { - } & \text { Likely availability of fuel (during emergency events) } \\
\text { - } & \text { Gas customer service days at risk of loss }{ }^{58} \\
\text { - } & \text { Designated critical asset service days at risk of loss from a gas supply failure } \\
\text { - } & \text { Nost of restoration of service } \\
\text { - } & \text { Identified measures for climate-change resiliency of gas pipes are being implemented } \\
\text { - } & \text { Percent of gas pipes hardened against water infiltration from sea level rise, storm surge, flooding } \\
\text { - } & \text { Number of miles of cast iron and bare steel gas mains in the } 500-y e a r \text { floodplain } \\
\text { - } & \text { Percentage of liquid fuel assets in the floodplain hardened against flood events }\end{array}$ \\
\hline
\end{tabular}




\begin{tabular}{|c|c|c|}
\hline & & $\begin{array}{l}\text { - Percentage of Liquid fuels facilities with anchored storage tanks that are } 50 \text { gallons or larger } \\
\text { - } \quad \text { Percentage of gas stations with quick-connects for generators } 60 \\
\text { Fuel plans } \\
\text { - } \quad \text { Program or plan for allocating fuel supplies to emergency responders first }\end{array}$ \\
\hline \multicolumn{3}{|c|}{ 10. Community Outreach \& Public Engagement } \\
\hline $\begin{array}{l}\text { Public awareness and } \\
\text { participation (public } \\
\text { input and response) }\end{array}$ & 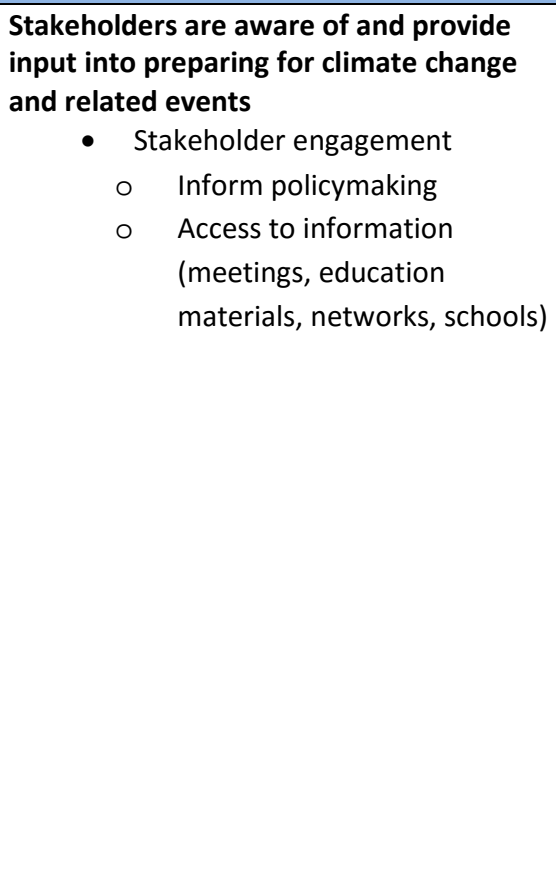 & $\begin{array}{l}\text { Stakeholder engagement } \\
\text { - The degree to which the public and specific stakeholders are aware of and provide input into preparing for } \\
\text { climate change and related events } \\
\text { Q } \quad \text { Quality of stakeholder engagement in decision-making to address climate change }{ }^{61} \\
\text { meetings, school curriculum) } \\
\text { - Neighborhood-based programs are developed to increase climate preparedness } \\
\text { - } \quad \text { Public, property owners and tenants are aware of their climate change vulnerabilities } \\
\text { - } \quad \text { Mechanisms are researched to provide property owners financial and technical support for increasing } \\
\text { preparedness } \\
\text { - } \quad \text { Number of jobs created or number of job training sessions top help address climate change preparedness } \\
\text { - } \quad \text { Social connectedness and neighborhood cohesion (e.g., likeliness that residents will be contacted after an } \\
\text { event to confirm safety, issues) } \\
\text { - } \quad \text { Public outreach is conducted to neighborhood groups to motivate all sectors of the community around } \\
\text { preparedness and better understand needs/priorities } \\
\text { - } \quad \text { Exposure of public to education and awareness materials/messaging } \\
\text { - } \quad \text { Validation of effectiveness of education } \\
\text { - } \quad \text { Availability and take-up of training } \\
\text { - } \\
\text { - } \\
\text { owcessibility of education and training to all linguistic groups in city } \\
\text { - Number of/Attendance at training courses, workshops and seminars presented to residents, property } \\
\text { Number of neighborhoods where public opinion is used to identify where key vulnerabilities exist }\end{array}$ \\
\hline & & $\begin{array}{l}\text { - } \\
\text { - } \quad \text { Vercentage of Public that accept climate change needs to be addressed } \\
\text { - } \quad \text { Percentage of meetings for xyz purposes are well attended } \\
\text { - } \quad \text { Awareness among stakeholders of climate change issues, risks and responses } 63 \\
\text { - } \quad \text { Visits to website on climate change risk or publicizing publications regarding reducing risks } \\
\text { - } \quad \text { Curriculum developed on climate change and preparedness; Regulation implemented to require teachers } \\
\text { to teach about climate change and preparedness; \# of teachers provided with curriculum on climate change and } \\
\text { preparedness } \\
\text { - } \quad \text { Number of individuals pledging to make key preparedness measures in their homes and businesses } \\
\text { Individuals are equipped to take action against climate change impacts }\end{array}$ \\
\hline
\end{tabular}




\section{Endnotes}

1 United Nations Office for Disa ster Risk Reduction (UNISDR), 2014, Disaster Resilience Scorecard for Cities, Working Doc ument, prepared by AEC OM and IBM, available from: http:// www.unisdr.org/2014/campaign-cities/Resilienc e\%20Sc orecard\%20V1.5.pdf, 17.

2 lbid., 18, 55-6.

3 lbid., 20.

$4 \mathrm{lbid} ., 20$. Bours, D., C. McGinn, and P. Pringle, 2014, Guidance note 3: Theory of Change approach to climate change adaptation programming, SEA Change and UKCIP, February, available from: http://www.sea changecop.org/node/2933.

5 Intemational Institute for Environment and Development (IIED), 2013, Ind ic ator 1: Climate change integration into planning, available from: http://pubs.iied.org/G03525.html.

6 IIED, 2013, Indic a tor 6: Planning under Uncertainty, a vaila ble from: http://pubs.iled.org/G 03536.html.

7 UNISDR, 5.

$8 \mathrm{lbid} ., 11$.

9 IIED, 2013, Indic a tor 5: Use of c limate information, ava ila ble from: http://pubs.iied.org/G03535.html.

10 UNISDR, 50.

11 IIED, 2013, Indic ator 2: Institutiona I c oordination for integration, a va ila ble from: http://pubs.iied.org/G 03526.html.

12 UNISDR, 6.

$13 \mathrm{lbid}, 30$.

14 Ibid., 30-1.

15 Ibid., 31.

16 lbid., 31.

17 lbid., 13.

18 The City of New York, 2014, Pla NYC Progress Report 2014, 89.

19 IIED, 2013, Indicator 3: Budgeting and finance, a vaila ble from: http:// pubs.iied.org/G 03527.html.

20 UNISDR, 11

$21 \mathrm{lbid} ., 37$.

22 lbid., 15-6, 33, 36-7, 49

23 lbid., 43.

24 The City of New York, 89.

$25 \mathrm{lbid}$.

26 lbid.

27 IIED, 2013, Indic ator 9: Vulnerability/resilience, a vaila ble from: http:// pubs.iied .org/G 03539.html.

28 UNISDR, 9, 39-41, 45

29 lbid., 6.

30 UNISDR, 53-4.

31 The City of New York, 89.

32 lbid.

33 UNISDR, 33. 
34 Ibid., 33-4.

35 UNISDR, 27

36 lbid., 28.

37 lbid., 28-9.

38 Ibid., 29.

39 lbid., 29-30.

40 The City of New York, 89.

41 Ibid.

42 UNISDR, 48.

43 The City of New York, 89

44 UNISDR, 25-6.

45 lbid.

46 The City of New York, 89.

47 UNISDR, 22-3.

$48 \mathrm{lbid}$.

49 Ibid., 23.

50 lbid., 24.

51 Ibid., 24.

52 The City of New York, 89.

53 lbid.

54 Notre Dame Global Adaptation Index Overview (ND-GAIN), 2013, Deta iled methodology report, 32-33, ava ila ble from:

http:// www3.nd.edu/ nchawla/methodology.pdf.

$55 \mathrm{lbid}$

56 The City of New York, 89.

57 UNISDR, 26.

58 Ibid., 26-7.

59 The City of New York, 89.

60 lbid.

61 IIED, 2013, Indic ator 7: Partic ipation, a vailable from: http://pubs.iied.org/G 03537.html.

62 UNISDR, 10

63 IIED, 2013, Indicator 8: Awa reness a mong sta keholders, a va ilable from: http://pubs.iied.org/G 03538.html. 